\title{
1259 (R.) (1843 M.) Senesi Aydın Sancağı Masarifat Muhasebesi Defterinin Çözümlenmesi
}

\author{
The Analysis of Coasts Accounting Book of Aydın Sanjak 1259 (R.) (1843 M. ) Year
}

\section{Ali Apalı}

Muhasebe Finansal Yönetim Bölümü, Mehmet Akif Ersoy Üniversitesi, Burdur, Türkiye

Özet

Osmanlı Devleti'nde taşra masarifat defterlerinin nahiye, kaza, sancak ve eyaletlerde kayıtlandığı arşiv belgelerinden anlaşılmaktadır. Başbakanlık Osmanlı Arşivleri'nde Osmanlı Devleti masarifat muhasebesine ait çok çeşitli defter mevcuttur. Bu defterlerin tamamını incelemek böylesi bir çalışmanın kapsamını aşacağı için, sadece 4863 gömlek no ve ML.MSF.d. fon kodlu defterin çözümlenmesinin yapılmasımasarifat muhasebesi özelinde çalışmanın konusunu oluşturmuştur. Defter 1259 (R.) (1843 M.) senesinin Haziran ayına ait olup, bu tarih çalışmanın zaman sınırını oluşturmuştur. Masarifat defterinde Aydın Sancağı'nın Aydın Güzelhisarı, Köşkderesi, Köşk, İnce, Sultanönü, Dallıca, Sobuca, Mazun, Dalama, Ayasuluğ, Tire, Bayındır, Birgi, Ödemiş, Keles, Alaşehir, İnegöl, Nazilli, Kuyucak, Karacasu, Balyanbolu, Bozdoğan, Arpaz, Yenipazar, Amasya, Çine, Karpuzlu ve Şahme Kazaları ile Koçak, Çakıllı, Karapınar ve Kıran Nahiyeleri olmak üzere toplam otuziki yerleşim yerine ait memur maaşları ve çeşitli masraf kalemlerinin kayıtları bulunmaktadır. Bu kayıtların yer aldığı masarifat defterinin çözümlenmesi sonucu elde edilen bilgilerin muhasebe tarihine kazandırılması çalışmanın amacı olarak belirlenmiştir. Anahtar Kelimeler:Muhasebe Tarihi,Aydın Sancağı, Masraf Muhasebesi.

Jel Kodu: M40, M49, N95

Abstract

It can be understood from the archival documents that provincial cost books were registered in townships, districts and provinces in the Ottoman Empire. There are a wide variety of books related to costs accounting of Ottoman Empire in the Prime Minister's Ottoman Archives. For examining all of these books will go beyond the scope of such study, doing the analysis of book with only 4863 case no and ML.MSF.d. fund code has been the subject of this study specific to costs accounting. The book belongs to June, 1259 (R)(1843 M.), creating the date limit of this historical work. The costs book includes records of staff salaries and various expense items belonging to a total of thirty-two settlements, including the districts Aydın Güzelhisarı, Köşkderesi, Köşk, İnce, Sultanönü, Dallıca, Sobuca, Mazun, Dalama, Ayasuluğ, Tire, Bayındır, Birgi, Ödemiş, Keles, Alaşehir, İnegöl, Nazilli, Kuyucak, Karacasu, Balyanbolu, Bozdoğan, Arpaz, Yenipazar, Amasya, Çine, Karpuzlu and Şahme, and the townships Koçak, Çakıllı, Karapınar and Kıran in Aydın Sanjak. The main goal of the present study is to introduce the data obtained from the analysis of costs book in which these records are included into the accounting history.

Keywords: Accounting History, Aydın Sanjak, Costs Accounting.

Jel cod: M40, M49, N95.

CONTACT : Ali Apalı, aliapali.35@gmail.com, ORCID ID: orcid.org/0000-0002-3521-0150

Geliş Tarihi \& First Received : 12.10.2017

Kabul Tarihi \& Accepted : : 01.11.2017 


\section{Giriş}

Osmanlı Devleti'nde gelir ve giderler kayıtları, katipler yani muhasebeciler vasıtasıyla yerine getirilirdi. Devlet içerisinde gelir ve gider kayıtlarını takip eden muhasebeciler hem taşra hem de merkezde görev yapmaktaydılar. Taşrada ortaya çıkan gelir ve giderler önce taşra merkezinde toplanır.Burada giderler gelirlerden düşülür.Eğer bir taşranın kendi içerisinde gelir fazlalığı oluşmuş ise merkeze aktarılırdı.Ancak muhasebe kayıtları bakımından gelir ve giderlerin tutarlarının ne olduğuna bakılmaksızın, kayıtlanan muhasebe belgeleri, defterleri merkez (Başmuhasebe) muhasebede aktarılır ve orada saklanırdı.Osmanlı Devleti'nde oldukça fazla sayıda masraf defteri bulunmaktadır.Bu defterlerden Aydın Sancağı ile ilgili olanı çalışmanın devamında çözümlenmiştir.

\section{Masarifat Muhasebesi Defteri Hakkında}

Osmanlı Devleti'nin bütçe dengelerinin sağlanması için kendi içerisinde birçok sınıflandırma yapılmasına rağmen, esas olarak gelirler varidat muhasebeciliği, giderler ise masarifat muhasebeciliği olarak ayrılmıştır. Çalışmanın konu sınırı bakımından Başbakanlık Osmanlı Arşivleri'nden temin edilen 4863 gömlek no ve ML.MSF.d. fon kodlu masarifat defterinde, Aydın Sancağı'na bağlı kaza ve nahiyelerdeki memurların maaş ve müteferrik kalemlerden oluşan masraflar kayıtlanmıştır.Defter içeriğin anlaşılması açısından bilgilendirici bir açılış kaydı ile başlamakta olup, kaydın transkripsiyonu şu şekildedir;

Aydın Eyâletinde kâ'in bi 'z-zât idâreolunmakda olanAydın Sancâğ 'nda hâvî olunduğu mâ'lûmü'l-esâmi kazâların İki Yüz Elli Dokuz senesi Haziran'ı ibtidâsından nihâyetine kadar bir mâh zarfinda bi'l-cümle-i me'mûrîne i 'tâ olunan mâaş ve mâhiyeleri ile masârıfât-ı müteferrika-i sâ'irenin mikdârı.

Açılış kaydında, belgede, Aydın Eyaletine bağlı Aydın Sancağı'nın kazalarının 1259 (R.) (1843 M.)senesinin sadece Haziran ayına ait memurların maaşları, mahiyetleri ve çeşili masrafların miktarlarının gösterildiğinden bahsedilmişstir.

Masarifat defteri dört yaprak ve sekiz sayfadan oluşmaktadır. İlk ve son sayfaları boş bırakılmıştır. Defterde kayıtlı yerleşim yerlerinin sırası değiştirilmeden belgedeki haliyle incelenmiştir. Sadece belgedeki muhasebe kayıtlarının daha iyi anlaşılabilmesi amacı ile veriler ve bilgiler tablolaştırılmıştır.

\section{Aydın Sancağı Kaza ve Nahiyelerinin Masraflarının Muhasebe Kayıtları}

Masarifat defterinde Aydın Sancağı'nın Aydın Güzelhisarı, Köşkderesi, Köşk, İnce, Sultanönü, Dallıca, Sobuca, Mazun, Dalama, Ayasuluğ, Tire, Bayındır, Birgi, Ödemiş, Keles, Alaşehir, İnegöl, Nazilli, Kuyucak, Karacasu, Balyanbolu, Bozdoğan, Arpaz, Yenipazar, Amasya, Çine, Karpuzlu ve Şahme Kazaları ile Koçak, Çakıllı, Karapınar ve Kıran Nahiyeleri olmak üzere toplam otuz iki yerleşim yerine ait memur maaşları ve çeşitli masraf kalemleri kayıtlanmıştır.Belgede ilk olarak kayıtlanan yerleşim birimi Aydın Güzelhisar Kazası'dır.

\subsection{Aydın Sancağı Güzelhisar Kazası Masrafları}

Aydın kent merkezi konumundaki Güzelhisar Kazası, sancağın yönetim merkezi olduğu muhasebe defterinden anlaşılmaktadır. Defterin ilk kayıtlarını oluşturan Güzelhisar Kazası'nın üst düzey yönetici memurlarının maaşları, karantina dairesinin masrafları, ihtisab müessesesinin masrafları, neferat (askeri) personelin masrafları ve çeşitli masraf kalemlerinin olduğu kayıtlar bulunmaktadır. Bunların birincisi olan üst düzey memurların maaşları tablo 1a.'da gösterilmiştir. 
Tablo 1a. Güzelhisar Kazası Üst Düzey Memur Maaşları

\begin{tabular}{|c|c|c|c|c|}
\hline $\begin{array}{l}\text { Devletlü Müşîr }^{1} \\
\text { Paşa Hazretleri'nin } \\
\text { mâaş1 Fî şehr }{ }^{2} \\
\text { Guruş } \\
67500\end{array}$ & $\begin{array}{l}\text { İzzetlü defterdâr } \\
\text { Mehmed Şâkir } \\
\text { Efendi } \\
\text { Hazretleri'nin mâaşı } \\
\text { Fî şehr } \\
\text { Guruş } \\
11250\end{array}$ & $\begin{array}{l}\text { Bâ-sûret-i müstahdem }{ }^{3} \text {-i ketebe }{ }^{4} \text { mâhiyeleri }^{5} \\
2000 \text { Halîl İbrâhim Efendin } \\
2000 \text { Halîl Hilmi Efendi } \\
1500 \text { Kâtib-i tahrirât }{ }^{6} \text { Mehmed Emîn Efendi } \\
1500 \text { Hasan Tahsin Efendi } \\
1000 \text { Ahmed Raşid Efendi } \\
0700 \text { Mehmed Şükrü Efendi } \\
\frac{0500}{9200} \text { Nedim Necâti Efendi } \\
\frac{1250}{7950} \text { Tevkif der aliye mâaş-1 İbrahim }\end{array}$ & $\begin{array}{l}\text { Nazır-1 defter -i } \\
\text { nüfüs }{ }^{7} \text { Hâc1 } \\
\text { Hüdâverdi Bey } \\
\text { Mâaşı } \\
\text { Fî şehr } \\
\text { Guruş } \\
500\end{array}$ & $\begin{array}{l}\text { Nüfüs } \\
\text { mukayyidi }^{8}{ }^{8} \\
\text { Hâcı Nuri } \\
\text { Efendi } \\
\text { Mâhiyesi } \\
\text { Fî şehr } \\
\text { Guruş } \\
250\end{array}$ \\
\hline
\end{tabular}

Tablo 1a'da Aydın Sancağı'nın Güzelhisar Kazası'ndaki üst düzey memurların maaşları gösterilmiştir. Buna göre en yüksek maaşı sancak yöneticisi konumundaki müşir 67.500 kuruş olarak almıştır. Ikinci en yüksek maaşlı yönetici, sancağın mali işlerinden sorumlu olan defterdara, 11.250 guruş olarak ödenmiştir. Nüfus nazırı ise 500 guruşluk bir maaş almıştır. Yine nüfus işleri ile ilgilenen mukayyid 250 guruş maaş almaktaydı.

Osmanlı Devleti mali sistem içerisinde altı asır boyunca muhasebeyi ve muhasebeciyi önemsemiştir. Bunun en iyi kanıtlarını muhasebe belgelerinde bulmak mümkündür.Bu kanıtlardan bir tanesi bu belgede yer almıştır.Şöyle ki, muhasebe görevini üstlenen kişilerin kayıtları kazada (ki bu kaza merkez kaza niteliğindedir) üçüncü sırada yer almıştır. Maaş olarak da yine kazadaki en yüksek maaş alan üçüncü makamdaki kişilerdir. Belgeye göre kazadaki muhasebe işlerini yedi muhasebeci (katip-ketebe) yürütmekteydi. Bunların arasında en düşük maaş alan 500 guruş (ki bu bile nüfus nazırının maaşına denkti) alırken, en yüksek maaş alan ise 2000 guruş idi. Yedi muhasebecinin toplam maaş1 9200 guruş iken, "İbrahim" ismindeki muhasebecinin maaşından 1250 guruş kesildiği (tevkif edildiği) için muhasebecilere toplam 7950 guruşluk bir ödeme yapılmıştır. Aynı kazada karantina dairesinin bulunduğunu Tablo 1b'deki çalışan maaş ve masrafları açıklamaktadır.

Tablo 1b.Güzelhisar Kazası Karantina Memurlarının Maaşları ve Masrafları

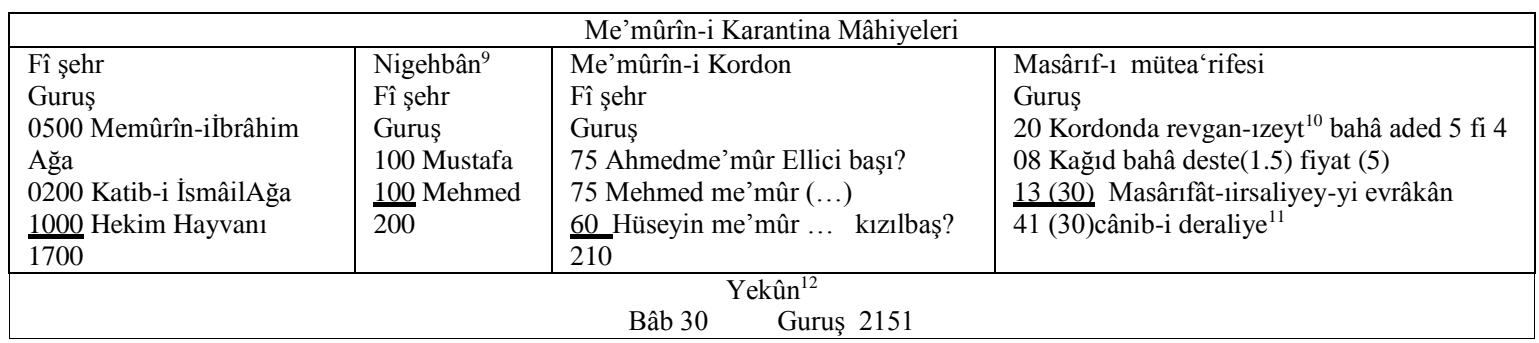

\footnotetext{
${ }^{1}$ Müşir: Maraşel, İdari yönden vali.

2 Şehr: 30 günlük süre, bir ay.

${ }^{3}$ Müstahdem: Hizmette bulunan, istihdam edilen.

${ }^{4}$ Ketebe: Yazıc1, Katip, Muhasebeci.

${ }^{5}$ Mahiye: Aylık.

${ }^{6}$ Katib-i Tahrirat: Resmi yazıșma katibi.

71831 yılından sonra eyalet ve sancaklarda nüfus işlerine bakmak üzere nüfus nazırlıkları kurulmuştur. Nazırlık müessesinde defter nazırı, mukayyid ve katipler görev yapardı. Defter nazırlıklarının görevleri, şehirlerde ve bağlı yerleşim birimlerinde doğanları ve yeni yerleşenleri kaydetmek, ölüm ya da başka sebeplerden yerlerşim biriminden ayrılanları da kayıtlardan düşmekti (Güneş, 2014: 227).

${ }^{8}$ Mukayyid: kaydedden kişi, katip.

${ }^{9}$ Nigehban: Bekçi

${ }^{10}$ Revgan-1 Zeyt: Zeytin yağı.

${ }^{11}$ Deraliye: istanbul.

12 Yekün: Toplam
} 
İlk defa sistemli olarak 1855 yılında Çanakkale' de kurulan karantina sistemi (Sarıyıldız, 2001: 464), içinde tutulan yedi çeşit muhasebe defteri bulunmaktadır. Bu defterleri Uyanıker (2014, 22-23), sandik defteri, gelir defteri, masraf defteri,koçanlı maaş defteri, idari merkezinehesap için tutulan defter, mülhakat ile ilgili olan hesab-I cari defter ve hesab-I cari pusulası şeklinde sıralamıştır. Büyük yerleşim yerlerinde ve riskli alanlarda kurulan karantina idarelerinde ortaya çıkan masraflar, ayrı bir defterde tutulurken, küçük yerleşim yerlerindeki karantina uygulamalarında ortaya çıkan masraflar ziyadesiyle genel masraf muhasebesi kayıtlarının içerisinde rastlanmaktadır.Belgenin bu kısmında da bu duruma örnek kayıtlar sözkonusudur.

Defterin karantina masraflarının yer aldığı kısmında karantina uygulamasında görevli memur maaşları ile çeşitli masraflar kayıtlanmıştır.Memurlar içerisinde en yüksek maaşı veteriner 1000 guruş alırken, en düşük maaşı ise, "Hüseyin" ismiyle kayıtlanan memur almaktadır.Diğer yandan karantina dairesinde yapılan masraflar üç kalemde muhasebeleştirilmiştir.Bunların toplamı 41 guruş olarak kaydedildikten sonra defterin bu kısmının altında karantina ile ilgili bütün masrafların bir aylık toplamı 2151 guruş olarak kayıt altına alınmıştır. Defterin devam eden kısmında ihtisab memurlarının masrafları bulunmaktadir.

Tablo 1c. Güzelhisar Kazası İhtisab Memurlarının Masrafları

\begin{tabular}{|c|c|c|c|}
\hline $\begin{array}{l}\text { Fî şehr } \\
\text { Guruş } \\
800 \text { Memûrîn-i Mehmed Ağa } \\
200 \text { Katib Hafiz İsmâil Efendi } \\
150 \text { Sarraf }{ }^{13} \text { Mihail } \\
\frac{100}{1250} \text { Kol memuru }^{14} \text { Ali }\end{array}$ & $\begin{array}{l}\text { Me'mûrîn-i kolciyân } \\
\text { Şehr } \\
\text { Guruş } \\
80 \text { Hamdullah } \\
80 \text { Mustafa } \\
80 \text { Mahmûd } \\
\underline{80} \text { Ömer } \\
320\end{array}$ & $\begin{array}{l}\text { Me'mûrîn-i zindân }{ }^{15} \\
\text { Fî şehr } \\
\text { Guruş } \\
80 \text { Cemali me'mûr-1 bâb-1 Tire } \\
80 \text { Mustafa bâb-1 Sobuca } \\
80 \text { Mehmed me'mûr-1 bâb-1 Nazilli } \\
80 \text { Ahmed me'mûr-i bâb-1 Atça } \\
\underline{50} \text { Ali Yamaği? }\end{array}$ & $\begin{array}{l}\text { Kantar ve killeciyân }{ }^{16} \\
\text { Fî şehr } \\
\text { Guruş } \\
70 \text { Mustafa } \\
70 \text { Hüseyin } \\
60 \text { Kileci Hacı Hüseyin } \\
\frac{60 \text { Hafız Ömer }}{260}\end{array}$ \\
\hline \multicolumn{2}{|c|}{$\begin{array}{l}\text { Me'mûrîn-i zikr-i atî kazâ ve nâhiye } \\
\text { Fî şehr } \\
150 \text { Kazâ-yı Köşk ve Köşk deresi Hacı Mustafa }\end{array}$} & \multicolumn{2}{|c|}{$\begin{array}{l}\text { Masarifat Müteferrikasi } \\
\text { Guruş } \\
60 \text { Kağıt baha Aded } 1 \text { (fi } 60 \text { kuruş) } \\
70 \text { defter baha Aded 4, (fi } 17.5 \text { kuruş) } \\
\frac{14}{14} \text { Mürekkeb Dirhem } 100 \text { fi } 40 \text { kalem-i çubuk adet } 20\end{array}$} \\
\hline \multicolumn{4}{|c|}{ Yekûn } \\
\hline
\end{tabular}

"Memûrîn İhtisâb Mâhiyeleri” bilgisi ile başlayan kayıtlarda en yüksek memur maaşının 800 guruş ile kayıtlanan ve ihtisab müessesinin başı niteliğindeki kişiye ödenmiştir.Belgeye göre en yüksek ikinci maaşı muhasebeci niteliğindeki katip almaktadır. Katibin maaş1 200 guruş olarak muhasebeleştirilmiştir. Kolciyanlar dört kişi olup bunların maaşları toplam 320 guruştur.Beş zindan memurukayıtlanmış, bunlardan biri 50 guruş dördü ise 80 'er guruş maaş almaktadırlar. Belgenin devamında killeci ve kantar görevlileri de dört kişi olarak kayıt altına alınmıştır. Bunlardan ikisi 70 guruş maaş alırken diğer ikisi ise 60 guruş maaş almaktaydılar.

Belgenin devam eden kısmında Köşk ve Köşkderesinin önde gelen memuru olan "Hacı Mustafa" ismindeki kişiye ödenen 150 guruş maaş ile çeşitli masrafların kayıtları

\footnotetext{
${ }^{13}$ Sarraf: Değerli maden ve kağıtları alıp satan kişiler

${ }^{14} \mathrm{Kol}$ memuru: Güvenlik görevlisi

${ }^{15}$ Zindan: Cezaevi, Suçluların konulduğu yer altı hapishanesi.

${ }^{16}$ Killeciyan: Sıvı şeyleri ölçen kişiler.
} 
gösterilmiştir. "Masarifat Müteferrikasi” bilgi notu ile 1 adet kağıt 60 guruş, tanesi 17,5 guruş olan 4 adet deftere 70 guruş ve 20 adet çubuk kalemli tanesi 100 dirhemden 14 guruşa mürekkeb alınmış ve bunların toplamı 144 guruş olarak kayıtlanmıştır. En sonunda ise 144 guruş olarak ihtisab memurlarının masrafları yekünlenmiştir.Sözkonusu kayıtların bu derece açıklanması muhasebe kavramlarından tam açıklama kavramına örnek teşkil etmektedir. Günümüzden yaklaşık iki asır önce kayıtlanan masrafların detaylı bir şekilde açıklanması tam açıklama kavramının yanı sıra önemlilik kavramını da ilgilendirmektedir.

Belgenin ikinci sayfasının devamındaGüzelhisar Kazası'nın askeri personelinin masrafları yer almaktadır.

Tablo 1d. Güzelhisar Kazası Askeri Personelin Masrafları

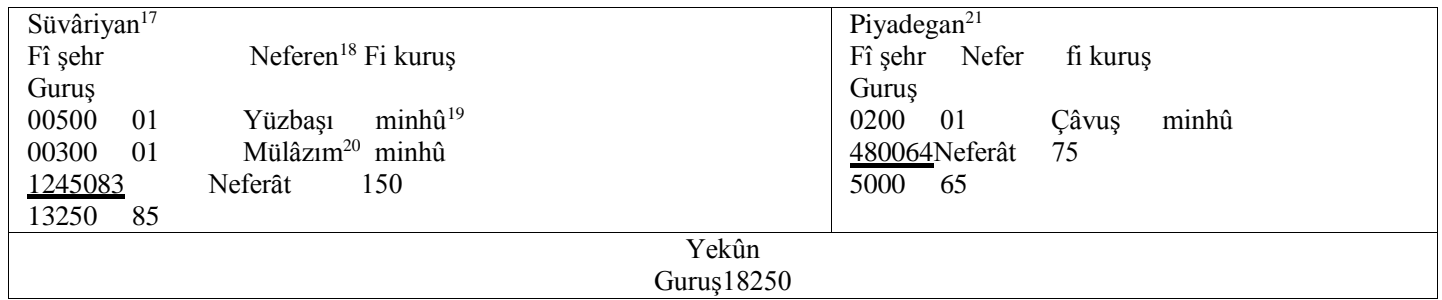

Defterde, "Müstehdem neferat mahiyeleri" kaydı ile askeri hizmette bulunan kişilerin masrafları kayıtlanmıştır. Süvari ve piyade olmak üzere iki kısımda kaydedilen askeri personelden en yüksek maaşı yüzbaşı rütbesindeki kişi500 guruş olarak almaktadır. İkinci ve üçüncü en yüksek, 300 guruş ve 200 guruş maaşalan kişilerdir. Neferat olarak kayıtlanan askerlerden atlı olanlar 83 kişi olup, bunlara 150'şer guruştan toplam 12450 guruş maaş ödenmiştir. Yaya olan 64 askere ise 75 'şer guruştan toplam 4800 guruş maaş ödenmiştir. Belgeye göre atlı askeri personelin toplam maaş1 13250, yaya askeri personelin ise 5000 guruş olmak üzere kazadaki askeri personele aylık toplam 18250 guruş olarak yapılan ödeme "yekün" hanesinde muhasebeleştirilmiştir.Belgenin devamında ise posta hayvanat müdürünün ve sandık emininin maaşları kayıtlanmıştır.

Tablo 1e.Güzelhisar Kazası Posta Müdürü ve Sandık Emini Maaşları

\begin{tabular}{|c|c|}
\hline Posta Hayvanâtı Müdürü Ali Ağa mâhiyesi & Sandık emini ${ }^{22}$ haymacı mâhiyesi \\
Fî şehr & Fî şehr \\
Guruş & Guruş \\
250 & 500 \\
\hline
\end{tabular}

Tablo 1e'ye göre posta hayvanat müdürüne 250 guruş ve sandık eminine 500 guruş maaş verilmiştir. Devam eden kısımda çeşitli masraflar kayıtlanmıştır.

\footnotetext{
${ }^{17}$ Süvariyan: Atl1 askerler

${ }^{18}$ Nefer: Asker

${ }^{19}$ Minhu: Ondan, Onun

${ }^{20}$ Mülazım: Teğmen.

${ }^{21}$ Piyedayan: Yaya askerler.

${ }^{22}$ Sandık Emini: Veznedar.
} 


\section{Tablo 1f.Güzelhisar Kazası Çeşitli Masraflar}

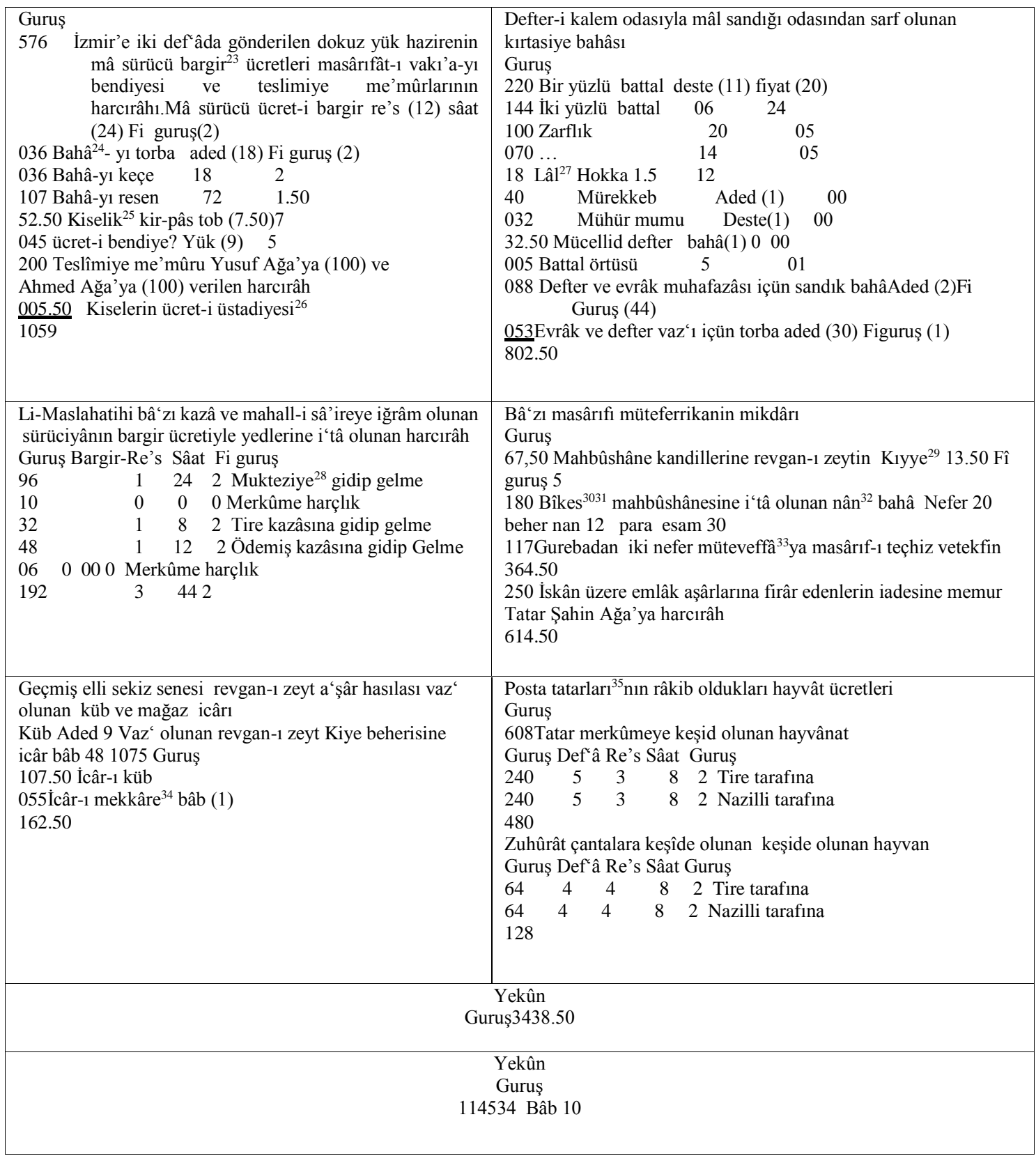

\footnotetext{
${ }^{23}$ Bargir: Yük taşıyan, Beygir.

${ }^{24}$ Baha: Bedel.

${ }^{25}$ Kise: Küçük torba.

26 Üstadiye: İşçilik.

${ }^{27}$ Lal: Kırmızı renkli mürekkep.

${ }^{28}$ Mukteziye: Gerekli olan, icab eden.

${ }^{29}$ Kıyye: Ăğrlık ölçüsü

${ }^{30}$ Bikes: Kimsesiz.

${ }^{31}$ Bikes: Kimsesiz.

${ }^{32}$ Nan: Ekmek.

${ }^{33}$ Mütevaffa: Müslüman olmayan, ölmüş kimse.

${ }^{34}$ Mekkare: Yük taşıyan hayvanlar.

${ }^{35}$ Posta tatarları: Ülkede haberlerşmeyi sağlayan kişiler.
} 
Tablo 1f' de Güzelhisar Kazası'nda ortaya çıkan çeşitli masraflar gösterilmektedir.Tablo da harcırah,zarlılık ve keçenin yer aldığı masraf kalemleri belirli bir düzenden bağımsız olarak kayıt altına alınmıştır.En yüksek masraf kalemi, 576 guruş olan İzmir'e giden memurların harcırahı olurken, en düşük masraf kalemi ise 5 guruş ile battal örtüdür.Masraf kalemlerinin kayıtları belgede devam etmektedir.

Tablo 1f.'de diğer kazalar arasında beygirlerle gidip gelenlere ödenen harcırah tutarları ile çeşitli kalemlerde harcanan tutarlar kaydedilmiştir. Osmanlı Devleti'nin muhasebe sisteminin ayrıntılı olarak tutulduğunun iyi bir göstergesi olan harcırah tutarlarında beygirlerin saat ücreti, kaç saat çalıştıkları, kaç adet beygirin görev yaptığı ve bunun karşılığında ne kadar aldıkları muhasebe kayıtlarında yer almıştır. Belgenin devam eden kısmında geçmiş yıllardan aktarılan zeytın yağları da kayıtlanmıştır. Aktarılan zeytin yağları ve çeşitli masraflar karışık şekilde gösterilmiştir. Aydın Sancağı Güzelhisar Kazası'na ait çeşitli masrafların toplamı 3438.50 guruş olarak kayıtlanmıştır. Diğer yandan bütün kazanın masrafları 114.534 guruş olarak muhasebeleştirilmiştir.Belgede ayrıca küçük de olsa toplama işlemi hatası bulunmaktadır.Kazanın bütün masraf toplamları alınırken 0,5 guruş fazla hesaplanmıştır. Bu fazla toplamanın kaynağı çeşitli masraflardadır. Çeşitli masrafların toplamı 3438,5 guruş olduğu halde genel toplama 3439 guruş olarak aktarılmıştır. Defterin devam eden kısmında Köşkderesi Kazası'nın masrafları kayıtlanmıştır.

\subsection{Köșkderesi Kazası Masrafları}

Tablo 2. Köşkderesi Kazasının Masrafları

\begin{tabular}{|c|c|}
\hline Nüfüs Müdürü & Müstahdem Neferâtı Mâhiyesi \\
\hline Hüseyin Efendi mâhiyesi & Piyadagân \\
\hline Fî şehr & Fî şehr \\
\hline Guruş & Neferen \\
\hline 100 & 1 Çavuş Fi guruş minhû \\
\hline Kazâ-y1 minhû guruş 50 & 14 Neferât 75 \\
\hline Kazâ-yı Köşk guruş 20 & 1250 \\
\hline Kazâ-yı Dallıca guruş 30 & \\
\hline \multicolumn{2}{|c|}{$\begin{array}{c}\text { Yekûn } \\
\text { Guruş } 1350\end{array}$} \\
\hline
\end{tabular}

Köşkderesi Kazası'nın masrafları nüfus müdürünün ve askeri personelin maaşlarından oluşmaktadır. Tablo 2'de gösterildiği üzere nüfus müdürü üç yerleşim yerinin sorumluluğuna sahiptir. Köşkderesi, Köşk ve Dallıca Kazalarından almış olduğu maaşlar sırasıyla 50 guruş, 20 guruş ve 30 guruş olup, toplam maaşı 100 guruş olarak kayıtlanmıştır. Diğer yandan askeri personel olarak kazada 15 piyade neferi bulunup, bunlardan çavuş olan

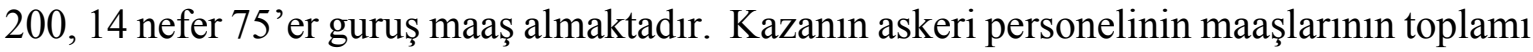
1250 guruş, kazanın toplam genel masrafları da 1350 guruş olarakmuhasebeleştirilmiştir. Belgenin devam eden kısmında Köşk Kazası masrafları kayıtlanmıştır.

\subsection{Köşk Kazası Masrafları}

Tablo 3. Köşk Kazası Masrafları

\begin{tabular}{|l|l|}
\hline \multicolumn{2}{|c|}{ Müstahdem Neferât Mâhiyesi } \\
\hline Süvâri & Piyadegân \\
Neferen & Neferen \\
1 Fî guruş minhu & 8 Guruş 75 \\
Fî şehr & Fî şehr \\
Guruş & Guruş \\
150 & 600 \\
\hline \multicolumn{2}{|c|}{ Yekûn } \\
\hline
\end{tabular}


Köşk Kazası'nda sadece askeri personel maaşlarına ait giderler kayıtlanmıştır. Buna göre süvari ve piyade askerlerden oluşan kayıtlardan 1 süvari asker 150 guruş maaş almakta, 8 piyade askeri ise 75 'er guruş maaş almaktadır. Kazanın toplam askeri masrafları 750 guruş olarak muhasebeleştirilmiştir. Masraf defterinin devam eden kısmında İnce Kazası masrafları bulunmaktadır.

\section{4.İnce Kazası Masrafları}

Tablo 4. İnce Kazası Masrafları

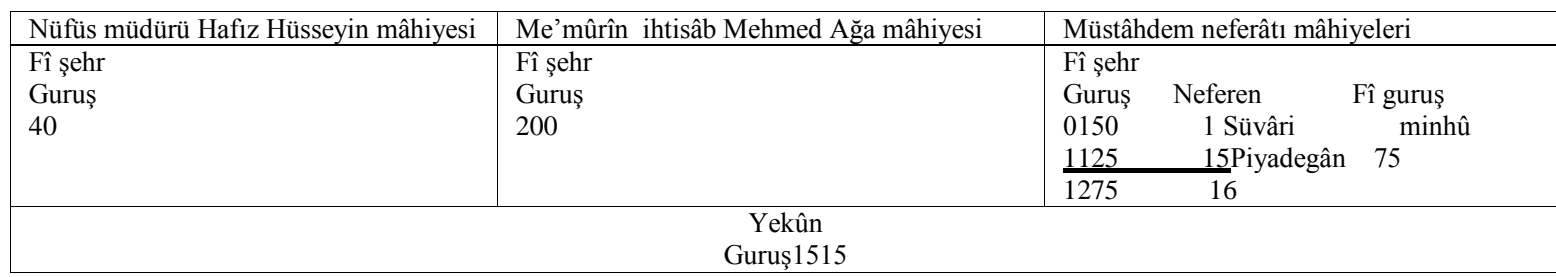

İnce Kazası'nın masrafları, nüfus müdürünün 40 guruşluk maaşı, ihtisab memurunun 200 guruşluk maaşı ve 1 süvarinin 150 guruş, 15 piyadenin de 75'er guruştan toplam 1125 gruşluk maaşları olarak üç grupta kaydedilmiştir. Bütün kazanın masrafları da yekün kısmına 1515 guruş olarak muhasebeleştirilmiştir.Defterde İnce Kazası masraflarından sonra Sultanönü Kazası masraflarına ait kayıtlar bulunmaktadır.

\subsection{Sultanönü Kazası Masrafları}

Tablo 5. Sultanönü Kazası Masrafları

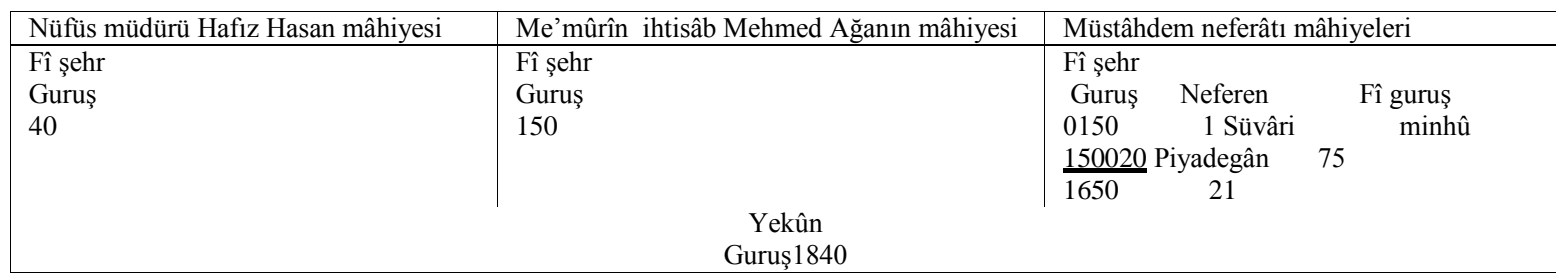

Sultanönü Kazası masrafları da İnce Kazası masrafları gibi üç kısımda kayıtlanmıştır.Birinci kısımda nüfus müdürünün 40 guruş olan maaşı, ikinci kısımda ihtisab memurunun 150 guruşluk maaşı bulunmaktadır. Üçüncü kısım askeri personelin maaş ödemelerine aittir.1 süvarinin maaş1 150 guruş, 20 piyadenin ise $75^{\prime}$ er guruştan toplam 1500 guruşluk maaşları kayıtlanmıştır. Kazanın toplam askeri personeline ödenen maaş, 1650 guruş iken, kazanın bir aylık masrafları ise, 1840 guruş şeklinde muhasebeleştirilmiştir. Belgenin devam eden kısmında Dallıca Kazası'nın masrafları yer almaktadır.

\subsection{Dallıca Kazası Masrafları}

Tablo 6. Dallıca Kazası Masrafları

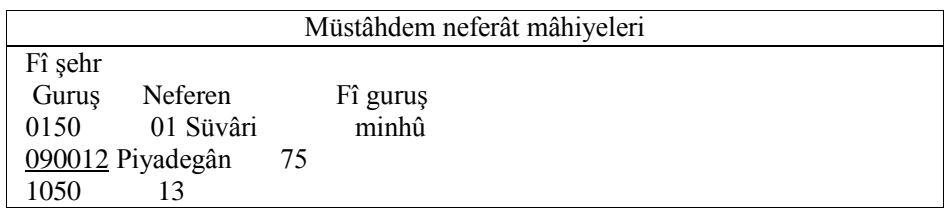

Dallıca Kazasında sadece askeri personele ait maaşlar yer almıştır.1 süvarinin maaşı 150 guruş, 12 piyadenin maaşı 75'er guruştan 900 guruş olarak kayıtlanmıştır. Kazanın toplam masrafi ise, 13 askeri personelin 1050 guruşluk maaş ödemesi olarak muhasebeleştirilmiştir.Belgede kayıtlanan bir sonraki kaza Sobuca Kazası'dır. 


\subsection{Sobuca Kazası Masrafları}

Tablo 7. Sobuca Kazası Masrafları

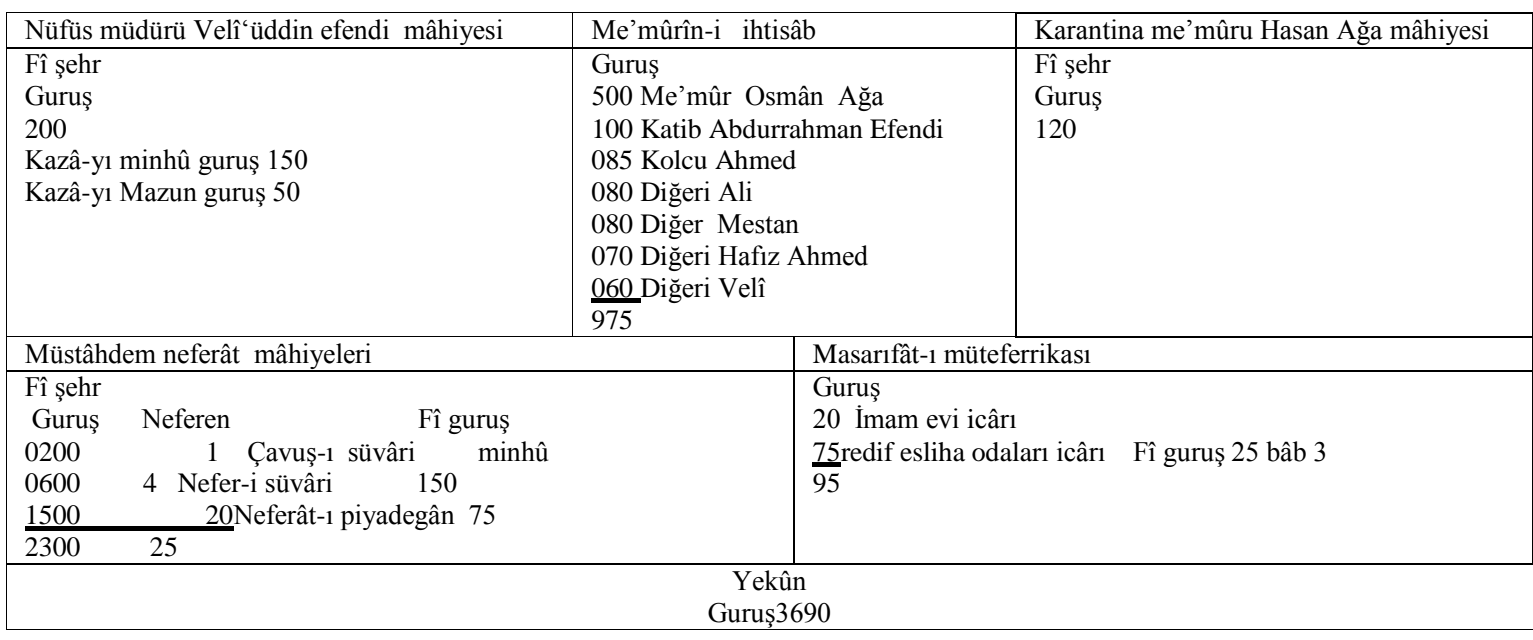

Sobuca Kazası masraflarının muhasebe kayıtlarına göre en yüksek tutarlı masraf kalemi, ihtisab memurunun maaşıdır.En düşük masraf kalemi ise, çeşitli masraflar kısmındaki imamın evinin icarına ödenen 20 guruşluk tutardır. Sobuca Kazası'nın diğer masrafları, nüfus müdürünün 200 guruş olan maaşı, ihtisab memurluğunun kalan 6 çalışanına ödenen 775 guruşluk maaş, karantina memuruna ödenen 120 guruş maaş, askeri personele ödenen 2300 guruş olan toplam maaş ve çeşitli masrafların kalan 75 guruşluk masrafidır.Kazanın toplam masrafı ise yekün hanesinde 3690 guruş olarak muhasebeleştirilmiş olup belgede kayıtlanan bir sonraki kaza Mazun Kazası'dır.

\subsection{Mazun Kazası Masrafları}

\section{Tablo 8.Mazun Kazası Masrafları}

\begin{tabular}{|l|}
\hline Müstâhdem neferât mâhiyeleri \\
\hline Piyadegân \\
Neferen7Fi guruş 75 \\
Fî şehr \\
Guruş \\
525 \\
\hline
\end{tabular}

Daha önce Sabuca Kazası muhasebe kayıtlarında nüfus memurunun Mazun Kazası için de görevli olduğu kayıtlanmıştı.Bu kısımda kaza ile ilgili sadece askeri personel maaşları gösterilmiştir.7 piyade askerin 75'er guruş olan maaşlarının toplamı 525 guruş olarak muhasebeleştirilmiştir. Defterin devam eden kısmında Karahayıt nam-1 diğer Dalama Kazasina aittir.

\subsection{Dalama (Karahayıt) Kazası Masrafları}

Tablo 9.Dalama (Karahayıt) Kazası Masrafları

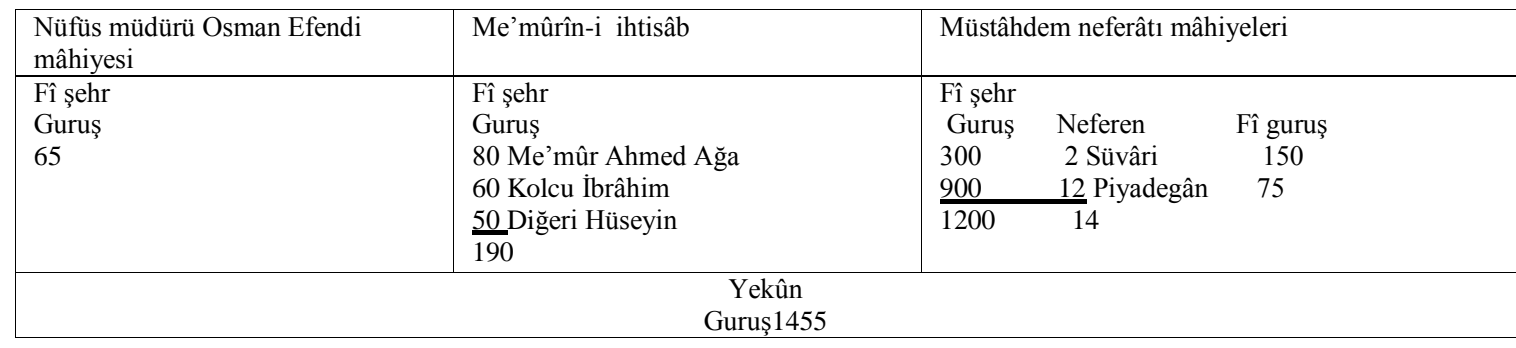


Dalama kazasının masraflarının tamamı kazada görev yapan memurlara ödenen maaşlardan oluşmaktadır.Üç kısımda kayıtlanan memur maaşlarının birinci kısmında nüfus müdürüne ödenen 65 guruş, ikinci kısımda ihtisab memurluğundaki üç kişiye ödenen 80, 60, 50 guruşluk ödemelerin muhasebe kayıtları yer almıştır. Üçüncü kısım kayıtları, 14 kişi olan askeri personel maaşlarından oluşmaktadır. Askeri personellerden 2 süvariye 300 guruş ve 12 piyadeye 900 guruş olmak üzere toplam 1200 guruş ödenmiştir. Böylece kazadaki memurların masraflarının toplamı 1455 guruş olarak muhasebeleştirilmişsir. Devam eden kısımda Koçak Nahiye ${ }^{36}$ si masrafları yer almıştır.

\subsection{Koçak Nahiyesi Masrafları}

Tablo 10. Koçak Nahiyesi Masrafları

\begin{tabular}{|l|l|}
\hline Me'mûr-1 ihtisâb Süleymân Ağa mâhiyesi & Müstahdem neferât mâhiyesi \\
\hline Fî şehr & Piyadagân \\
Guruş & Neferen (7) Fî guruş (75) \\
50 & Fi şehr \\
& Guruş \\
\hline \multicolumn{2}{|c|}{ Yekûn } \\
Guruş575 \\
\hline
\end{tabular}

İhtisab memuru ve askeri personelin maaşlarından oluşan Koçak Nahiyesinin masrafları belgede iki kısımda kayıtlanmıştır. Birinci kısımda ihtisab memurunun maaşı 50 guruş, ikinci kısımda toplam askeri personelin maaşı 525 guruş olarak gösterilmiştir. Askeri personel 4 neferden oluşmakta ve her birinin maaşı 75 guruştur. Nahiyenin toplam masrafı 575 guruş olarak muhasebeleştirilmiştir. Belgede kayıtlaan bir sonraki yerleşim birimi Çakıllı Nahiyesinin masraflarıdır.

\subsection{1. Çakıllı Nahiyesi Masrafları}

Tablo 11. Çakıllı Nahiyesi Masrafları

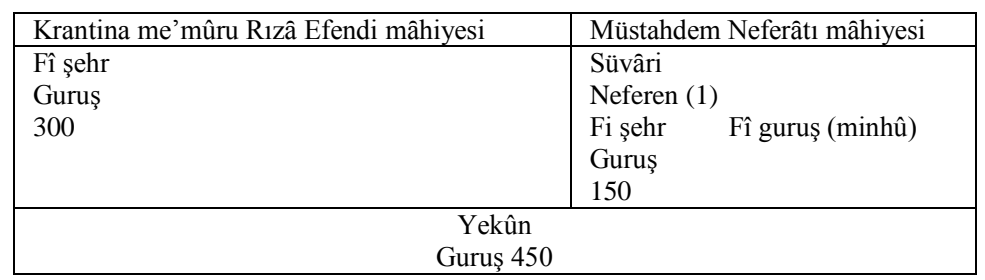

Çakıllı nahiyesinin masrafları 300 guruş olan karantina memurunun maaşı ile askeri personelin toplam 150 guruş olan maaşından oluşmaktadır. Sadece iki memur maaşından oluşan nahiye masraflarının toplamı, 450 guruş olarak muhasebeleştirilmiştir. Belgenin devamında Karapınar Nahiyesinin masrafları kayıtlanmıştır.

\subsection{Karapınar Nahiyesi Masrafları}

Tablo 12. Karapınar Nahiyesi Masrafları

\begin{tabular}{|l|l|}
\hline \multicolumn{2}{|c|}{ Müstahdem Neferâtı mâhiyesi } \\
\hline Süvâri & Piyadagân \\
Neferen (1) & Neferen (10) \\
Fi şehr Fi guruş (minhû) & Fî şehr Fî guruş (75) \\
Guruş & Guruş \\
150 & 750 \\
\hline \multicolumn{2}{|c|}{ Yekûn } \\
\multicolumn{2}{|c|}{ Guruş 900} \\
\hline
\end{tabular}

\footnotetext{
${ }^{36}$ Nahiye: Bucak, ilçe ile köy arası yerleşim yeri.
} 
Karapınar Nahiyesi'nin masrafları sadece 11 neferin maaşından oluşmaktadır. Askerlerden biri süvari olup maaşı 150 guruş olarak kayıtlanmış iken geriye kalanlar piyade olup, herbirinin maaş 75 guruştan toplam 750 guruş olmuştur. Nahiyenin toplam masrafı ise yekün hanesinde 900 guruş olarak muhasebeleştirilmiştir. Bir sonraki kısımda Ayasuluğ Kazası'nın masrafları yer almaktadır.

\subsection{Ayasuluğ Kazası Masrafları}

Tablo 13. Ayasuluğ Kazası Masrafları

\begin{tabular}{|c|c|c|}
\hline \multicolumn{3}{|c|}{ Müstahdem Neferât mâhiyesi } \\
\hline \multicolumn{3}{|c|}{ Fî şehr } \\
\hline Guruş & Neferât & Fî Guruş \\
\hline 0450 & 3 Süvâri & 150 \\
\hline 0900 & 12 Piyadegân & 75 \\
\hline 1350 & 15 & \\
\hline
\end{tabular}

Ayasuğ Kazası'nın toplam masrafı 12 askerin 1350 guruş olan maaşlarıdır. Askerlerden, üçü süvari olup 150'şer guruştan 450 guruş maaş almışlardır. Geriye kalan 12 piyade askerin ise maaşları 75 guruş olup toplam 900 guruş olarak kayıt altına alınmıştır. Belgenin devamında bölgenin en büyük yerleşim birimlerinden olan Tire Kazası masrafları yer almaktadir.

\subsection{Tire Kazası Masrafları}

\section{Tablo 14. Tire Kazası Masrafları}

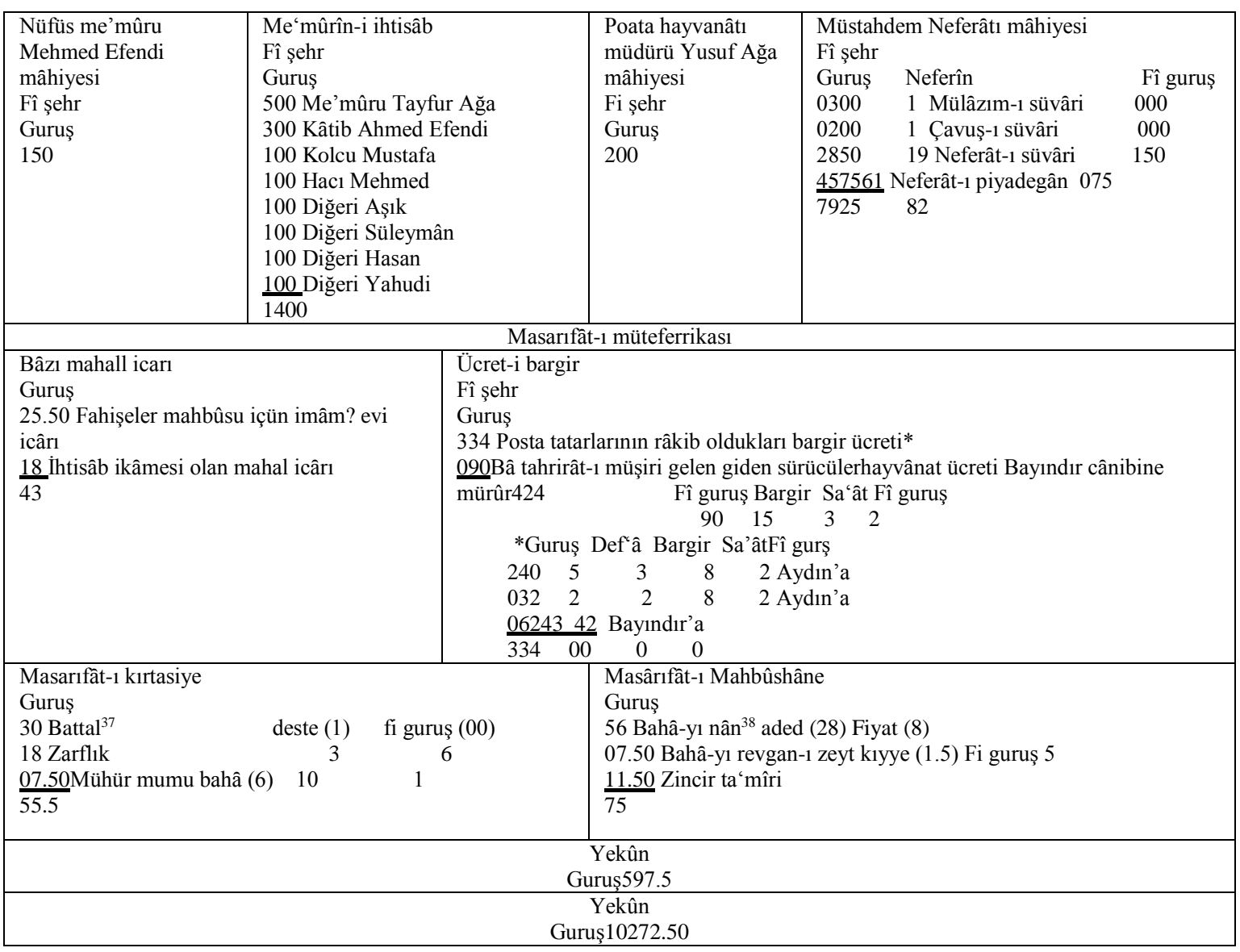

${ }^{37}$ Battal: İşi bitmiş resmi belgelerin konduğu torbalar.

${ }^{38}$ Nan: Ekmek. 
Tire Kazası Osmanlı Devleti'nin idari taksimatında her zaman önemli bir yere sahipti. Bazen kaza bazen sancak konumunda olan Tire Kazası'nın devlet içerisindeki önemi muhasebe kayıtlarından da anlaşılmaktadır. Kazanın masraf muhasebesi kayıtları genel olarak iki ana sınıflama ile kaydedilmiştir. Bunlardan birincisi kazada yer alan memur maaşları, ikincisi ise kazanın çeşitli idari birimlerinin masraflarıdır. Birinci kısım dört alt kısımda kayıtlanmıştır. Kayıtlardan birincisi nüfus memurunun 150 guruşluk maaşı, ikincisinde 8 çalışanı ile ihtisab memurluğunun toplam 1400 guruşluk maaşları, üçüncü alt kısımda posta hayvanlarının müdürü olan çalışana ödenen 200 guruşluk maaş ve son olarak toplam 7925 guruş olan askeri personele ödenen maaşlardır. Dördüncü gruptaki asker sayısı 82 olup, bunların içerisinde en yüksek maaşı günümüz teğmen karş1lığı olan süvari mülazımının 300 guruşluk maaşı yer almaktadır. Askeri personel içerisinde en düşük maaşlı olanlar 61 nefer olan piyadelerin 75 guruşluk maaşlarıdır. Bunların maaş toplamı 4575 guruş olarak kayıtlanmıştır. Diğer askeri personellerden, 1 süvari çavuş 200 guruş, 19 süvari nefer ise 150'şer guruş olarak aldıkları toplam 2850 guruş kayıt altına alınmıştır.

Defterin Tire Kazası masraflarının kayıtlandığı ikinci kısımda çeşitli kiralar, beygir ücretleri, kırtasiye masrafları ve mahpushane masrafları bulunmaktadır. Bu kısmın ilk kaydı olan kira masrafları 25.50 guruş ile fahişe hapishanesine ve 18 guruş ihtisab ikamesi olan bina için harcanmış olup bunların toplamı 43 guruş olarak muhasebeleştirilmiştir. İkinci kısımda yer alan beygirlerin ücretlerinde 334 guruş posta arabasına ve 90 guruş da posta arabacısı olan kişilere harcanmıştır. Bu iki harcamanın toplamı 424 guruş olarak muhasebeleştirilmiştir. Ayrıca posta tatarlarının ayrıntılı çizelgesi de kayıtlanmıştır. "Masarifat-1 mütefarrikası" başlıklı kısımın üçüncü alt kısmında battala 30 guruş, mühür mumuna da 7.50 guruş olmak üzere toplam 55.50 guruş ödeme yapılmıştır. Belgenin kaza ile ilgili olan son kısmında ise mahbushane için yapılan masraflar kayıtlanmıştır. Mahpushanede, nan için 56 guruş, zeytin yağı için 7.50 guruş ve zincir tamiri için ödenen 11.50 guruşun toplamı 75 guruş olmuştur. Böylece çeşitli masrafların toplamı, 597.50 guruş ve bütün kazanın toplamı da 10272.50 guruş olarak muhasebeleştirilmişsir. Belgenin devamında Bayındır Kazası masrafları bulunmaktadır.

\subsection{Bayındır Kazası Masrafları}

Tablo 15.Bayındır Kazası Masrafları

\begin{tabular}{|c|c|c|c|c|}
\hline $\begin{array}{l}\text { Nüfüs müdürü Mehmed } \\
\text { Efendi mâhiyesi } \\
\text { Fî şehr } \\
\text { Guruş } \\
300\end{array}$ & $\begin{array}{l}\text { Me'mûrîn-i ihtisâb } \\
\text { Guruş } \\
400 \text { Me'mûr Nazîf Ağa } \\
300 \text { Katib Mehmed Efendi } \\
075 \text { Kolcu Ahmed } \\
075 \text { Ve diğeri Mustafa } \\
075 \text { Diğeri Hazelmid? } \\
\text { 075 Diğgeri Yohan? } \\
1000\end{array}$ & \multicolumn{2}{|c|}{$\begin{array}{l}\text { Posta bargirleri } \\
\text { müdürü Ahmed } \\
\text { Ağa'nın mâhiyesi } \\
\text { Fî şehr } \\
\text { Guruş } \\
200\end{array}$} & $\begin{array}{l}\text { Müstâhdem neferât mâhiyeleri } \\
\text { Fî şehr } \\
0300 \quad \text { Neferen } 1 \text { mülâzım süvâri minhû } \\
\begin{array}{ll}3600 & 24 \text { neferât- } 1 \text { süvâri } 150 \\
2850 & 38 \\
6750 & 63\end{array}\end{array}$ \\
\hline \multicolumn{5}{|c|}{ Masârıfât-1 Mütea'rife } \\
\hline 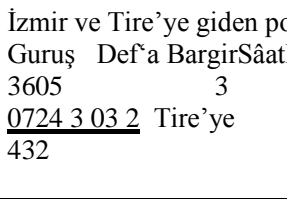 & $\begin{array}{l}\text { tatarlarının rakîb oldukları l } \\
\text { guruş } \\
2 \text { İzmir'e }\end{array}$ & gir ücreti & $\begin{array}{l}\text { Masâ } \\
\text { Gurus } \\
42 \mathrm{~B} \\
20 \mathrm{M} \\
\frac{02}{64} \mathrm{Ba}\end{array}$ & $\begin{array}{l}\text { xurtasiyenin mikdârı } \\
\text { kâğıd deste (7) Fi guruş (6) } \\
\text { b Hokka ( 200) minhû } \\
\text { îk }\end{array}$ \\
\hline $\begin{array}{l}\text { Masârıfât-1 mahbûshâne } \\
\text { Guruş } \\
30 \text { Kandiller içün revgan } \\
\frac{48}{78} \text { Bahâ-yı nân-i aziz ade }\end{array}$ & $\begin{array}{l}\text { eytin Kiyye (6) Fi guruş } 5 \\
\text { 192) bâb (10) }\end{array}$ & & $\begin{array}{l}\text { İhtisâ } \\
\text { Gurus } \\
25 \\
\frac{25}{50}\end{array}$ & hallinin iki aylık icârı \\
\hline \multicolumn{5}{|c|}{ Guruş624 } \\
\hline \multicolumn{5}{|c|}{ Yekûn } \\
\hline
\end{tabular}


Bayındır Kazası masrafları, memur maaşları ve çeşitli masraflardan oluşmaktadır. Memurlardan nüfus müdürü 300 guruş, altı kişi olan ihtisab memurlarının toplam maaşları 1000 guruş ve posta beygirlerinin müdürü de 200 guruş almaktadır. Askeri personel olarak 63 kişinin maaş aldığı kazada en yüksek maaşı teğmen rütbesi ile süvari mülazımı 300 guruş, en düşük maaş ise piyade askerlerinin 75 guruş olan maaşıdır. Askeri personelin 6750 guruş olan toplam maaşları içerisinde 24 süvari askeri 150'şer guruş maaş almaktadırlar.

Bayındır Kazasının çeşitli masrafları, 432 guruş olan posta beygirlerinin ücreti, 64 guruş kırtasiye masrafi, 78 guruş mahbushane masrafı ve ihtisab mahallinin iki aylık kirası olan 50 guruştan oluşmaktadır. Kazanın çeşitli masraflarının toplamı 624 guruş olarak, kazanın bütün toplamı ise 8874 guruş olarak muhasebeleştirilmiştir.Belgede kayıtlanan bir sonraki kaza ise Birgi Kazası'dır.

\subsection{Birgi Kazası Masrafları}

Tablo 16.Birgi Kazası

\begin{tabular}{|c|c|c|c|}
\hline $\begin{array}{l}\text { Nüfüs Müdürü Mehmed } \\
\text { Selim Efendi mâhiyesi } \\
\text { Fî şehr } \\
\text { Guruş } \\
280^{*}\end{array}$ & $\begin{array}{l}\text { Me'mûrîn-i İhtisâb } \\
\text { Fî şehr } \\
\text { Guruş } \\
400 \text { Me'mûr Mehmed } \\
\text { Ağa } \\
200 \text { Katib Hasan Efendi } \\
\text { 080 Kolcu Abdurrahman } \\
\text { 080 Diğeri Hasan } \\
\underline{080} \text { Diğeri Hâfız }\end{array}$ & 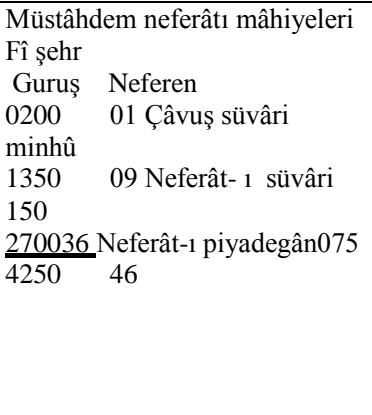 & $\begin{array}{l}\text { Masârıfât-1 müte'arife } \\
\text { Guruş } \\
18 \text { İhtisab-1 mahalli icârı } \\
100 \text { İzmire giden akçelik bargir } \\
\text { ücreti Re's } 2 \text { Guruş50 } \\
010 \text { Akçe-yi mezbûr içün torba } \\
\text { aded } 2 \text { guruş } 5 \\
004 \text { Bahâ-yı rişte Aded 4Guruş } 1 \\
030 \text { Mahbûshâneye revgan-1 } \\
\text { zeytin kiyye } 6 \text { Fî guruş } 5 \\
\text { 062 Bî kes mâhbusâna verilen } \\
\text { nân aded } 248 \text { Fiyât } 10 \\
224\end{array}$ \\
\hline
\end{tabular}

Birgi Kazası'nın masrafları nüfus 280 guruşluk maaşı ile kayıtlanmıştır. Birgi Kazası'nda kayıtlı olan nüfus müdürü Mehmed Selim Efendi, bu maaşın 100 guruşunu Birgi Kazası için, 60 guruşunu Keles Kazası için ve 120 guruşunu da Ödemiş Kazası için almaktadır. Birgi Kazası'nın ihtisab memurlarının maaşlarının toplamı 840 guruş, askeri personelin maaşlarının toplamı, 4250 guruştur.Kazadaki toplam askeri personel sayısı 46 nefer olup, bunun 1'i çavuş, 9'u süvari askeri, 36'sı ise piyade askeridir.Askerlerin maaşları sırası ile 200, 150 ve 75 'er guruştur.Kazanın son masraf kısmı herkesin bildiği masraflar olarak, kayıtlanan 224 guruşluk çeşitli harcamalardır.Kazanın toplam masrafı, 5594 guruş olarak muhasebeleştirilmiştir. Belgenin devam eden kısmında Ödemiş Kazası masrafları yer almaktadır.

\subsection{7. Ödemiş Kazası Masrafları}

\section{Tablo 17.Ödemiş Kazası Masrafları}

\begin{tabular}{|c|c|c|}
\hline $\begin{array}{l}\text { Me'mûrîn -i ihtisâb } \\
\text { Guruş } \\
600 \text { Me'mûr İsmâil Ağa } \\
150 \text { Kâtib Tâhir Efendi } \\
120 \text { Sarraf Tenayil Zimmî } \\
200 \text { İbrâhim me'mûr-1 karye-i Bademiye } \\
175 \text { İsmâil memur-1 karye-i Adalı } \\
120 \text { Kolcu Süleymân } \\
080 \text { Diğeri Ahmed } \\
080 \text { Diğeri Mehmed } \\
080 \text { Ve Ali } \\
\text { 080 Diğeri Süleymân } \\
\frac{050}{1735} \text { Diğer Mehmed }\end{array}$ & 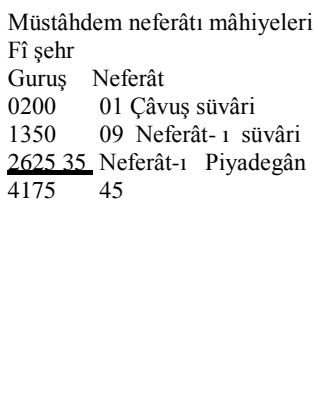 & $\begin{array}{l}\text { Masârıfât-1 müte'arife } \\
\text { Guruş } \\
40 \text { İhtiab-1 mahalli icârı } \\
250 \text { İzmir giden akçeni bargir ücreti e's 5Guruş } 50 \\
105 \text { Akçe-yi mezkûr içün torba Aded } 4 \text { Guruş } 32 \\
20 \text { Band içün rişt bahâ Aded } 10 \text { Guruş } 2 \\
\underline{030} \text { Akçe-i mezkûrı teslîmiyye me'mûrHüseyin'e verilen } \\
\text { harcırâh }\end{array}$ \\
\hline \multicolumn{3}{|c|}{$\begin{array}{c}\text { Yekûn } \\
\text { Guruş6265 }\end{array}$} \\
\hline
\end{tabular}


Ödemiş Kazası'nın masrafları üç kısımda kayıtlanmıştır. Kayıtların birinci kısmında 1735 guruş olan ihtisab memurluğunun maaşları, ikincisinde 4175 guruş olan askeri personel maaşları ve üçüncü kısmında ise 335 guruş olan çeşitli masraflar kayıtlanmıştır. İhtisab memurluğunda en yüksek maaş 600 guruş, en düşük maaş 50guruştur.Belgeye göre kazada görev yapan asker sayısı 45'dir.Bunun 1 'i çavuş, maaşı 200 guruş, 9'u süvari nefer olup toplam maaşları 1350 guruş ve 35'i piyade neferi olup, toplam maaşları 2625 guruş olarak kayıtlanmıştır.Belgede çeşitli masraflar kısmında kira, beygir ücreti, harcırah gibi masraf kalemleribulunmaktadır.Kazanın toplam masrafları ise 6265 guruş olarak muhasebeleştirilmiştir.Defterde kayıtlanan bir sonraki kaza Keles Kazası'dır.

\subsection{Keles Kazası Masrafları}

Tablo 18. Keles Kazası Masrafları

\begin{tabular}{|c|c|c|}
\hline $\begin{array}{lc}\text { Müstâhdem neferâtı m } \\
\text { Fî şehr } & \\
\text { Guruş } & \text { Neferât } \\
750 & 5 \text { Süvâri } \\
\frac{112515}{1875} & \text { Piyâdegân } 75 \\
\end{array}$ & $\begin{array}{l}\text { Fî guruş } \\
150\end{array}$ & $\begin{array}{l}\text { Bahâ-yı zarflık kâğıd deste } 4 \\
\text { Fî guruş } \\
5 \\
\text { Guruş } \\
20\end{array}$ \\
\hline \multicolumn{3}{|c|}{$\begin{array}{c}\text { Yekûn } \\
\text { Guruş1895 }\end{array}$} \\
\hline
\end{tabular}

Keles Kazası'nda masraf kaydı olarak sadece askeri personel ve toplam 20 guruş olan bir kalem masraf gösterilmiştir.Askeri personelin sayısı 20 olup, bunların 5'i süvari asker, 15 ' $i$ ise piyade askerdir.Süvari askerler 150 guruş alırken, piyade askerler 75 guruş almaktadırlar.Kazanın toplam askeri harcaması 1875 guruş, bütün masraflarının toplamı ise 1895 guruş olarak muhasebeleştirilmiştir. Devam eden kısımda Alaşehir Kazası'nın maaşları kayıtlanmıştır.

\subsection{Alaşehir Kazası Masrafları}

\section{Tablo 19.Alâşehir Kazası Masrafları}

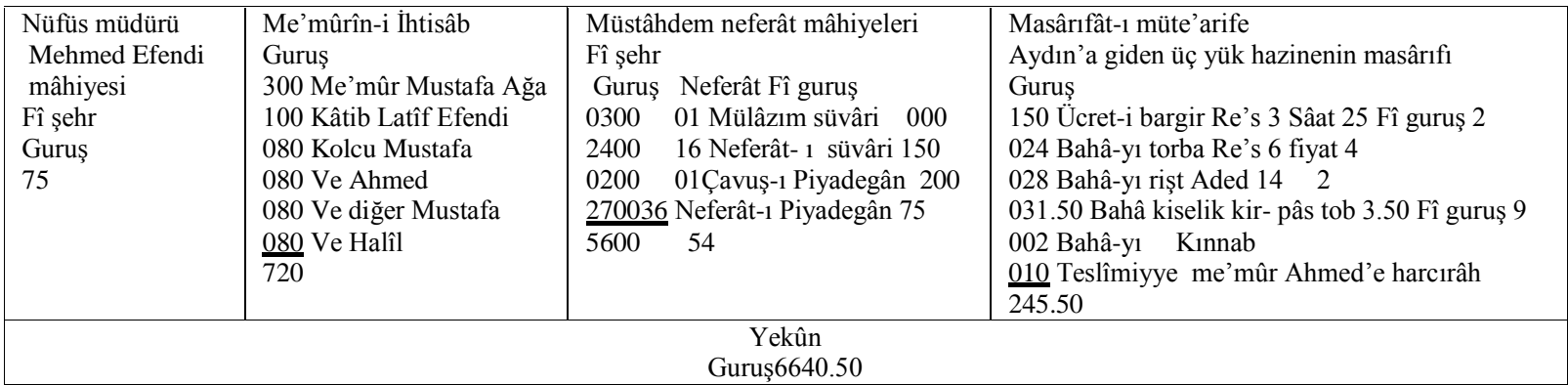

Alaşehir Kazası masrafları nüfus müdürüne ödenen 75 guruş ile başlamaktadır.Belgenin devamında ihtisab memurluğunun maaşları olan toplam 720 guruş kayıtlanmıştır. Ihtisab memurları içerisinde en yüksek maaş 300 guruş olarak ödenmişken, en düşük maaş ise 80 guruş olarak ödenmiştir. Kazadaki askeri personelin sayısı 54 nefer olup, bunlara 5600 akçe toplam maaş ödemesi yapılmıştır. Askerlerden teğmene 300 guruş, süvarilere 150'şer guruş, piyade çavuşuna 200 guruş ve piyade askerlerine $75^{\prime}$ 'er guruş maaş ödemesi yapılmıştır. Alaşehir Kazası'nın son kısmında Aydın merkeze giden hazinelerin masrafı başlığı ile toplam 245.50 akçe kayıt altına alınmıştır. Kazanın toplam masrafı, 6640.50 guruş olarak muhasebeleştirilmiştir.Bir sonraki kaza İnegöl Kazası'dır. 


\subsection{0. İnegöl Kazası Masrafları}

\section{Tablo 20.İnegöl (Aydın) Kazası Masrafları}

\begin{tabular}{|c|c|c|c|c|}
\hline $\begin{array}{l}\text { Nüfüs } \\
\text { müdürü } \\
\text { İbrâhim } \\
\text { Efendi } \\
\text { mâhiyesi } \\
\text { Fî şehr } \\
\text { Guruş } \\
60\end{array}$ & $\begin{array}{l}\text { İhtisâb } \\
\text { me'mûru } \\
\text { Mustafa } \\
\text { Ağa } \\
\text { mâhiyesi } \\
\text { Fî şehr } \\
\text { Guruş } \\
100\end{array}$ & $\begin{array}{l}\text { Müstâhdem } \\
\text { neferâtımâhiyeleri } \\
\text { Fî şehr } \\
\text { Guruş Neferen Fî guruş } \\
0750 \quad 5 \text { Süvâriyân } 150 \\
\frac{127017}{2025 \quad 22} \text { Piyadegân } 075\end{array}$ & 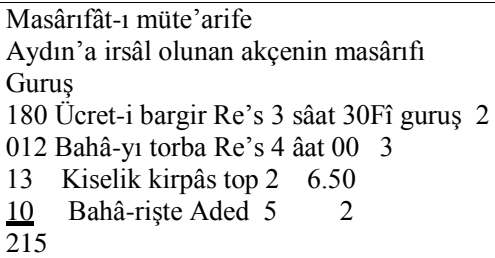 & $\begin{array}{l}\text { Bahâ-yı kâğıdMasârıfât-1 } \\
\text { mahbûshâne } \\
\text { Guruş } \\
\begin{array}{l}25 \text { Bahâ-yı kağıd Deste } 5 \text { Fîguruş } \\
5\end{array} \\
\begin{array}{l}\text { 22.50Mahbûshâneyerevgan kıyye } \\
\quad 5 \text { Fî guruş } 4.50 \\
47.50\end{array}\end{array}$ \\
\hline \multicolumn{5}{|c|}{$\begin{array}{c}\text { Yekûn } \\
\text { Guruş2447.50 }\end{array}$} \\
\hline
\end{tabular}

İnegöl kazası masrafları, beş kısımda kayıtlanmıştır. Bunlar; nüfus müdürüne yapılan 60 guruş maaş ödemesi, ihtisab memuruna yapılan 100 guruş ve askeri personele yapılan toplam 2025 guruş olarak kayıtlanan memur maaşları ile ilgilidir. Aydın Sancağı'na gönderilen yük için yapılan masraf ile mahbushanenin 47.50 guruşluk maaşları ise diğer iki kısımda kayıtlanan masraflardır. Kayıtlara göre kazadaki askeri personel sayısı 22'dir. Bunların 5'i 150 guruş maaş alan süvariler, 17'si 75 guruş maaş alan piyade neferidir. Kazanın memur ve çeşitli masraflarının toplamı 2447.50 guruş olarak muhasebeleştirilmiştir. Belgenin devam eden kısmında Nazilli Kazası'nın masrafları gösterilmiştir.

\subsection{Nazilli Kazası Masrafları}

Tablo 21.Nazilli Kazası Masrafları

\begin{tabular}{|c|c|c|c|c|}
\hline $\begin{array}{l}\text { Nüfüs } \\
\text { müdürü } \\
\text { Süleymân } \\
\text { Efendi } \\
\text { mâhiyesi } \\
\text { Fî şehr } \\
\text { Guruş } \\
50\end{array}$ & $\begin{array}{l}\text { Me'mûrîn-i ihtisâb } \\
\text { Guruş } \\
600 \text { Me'mûr Hüseyin } \\
\text { Ağa } \\
150 \text { Katib Ahmed Efendi } \\
100 \text { Kolcu Abdullah } \\
100 \text { ve Ahmed } \\
100 \text { Ve Veli } \\
\underline{100} \text { Ve Hüseyin } \\
1150\end{array}$ & 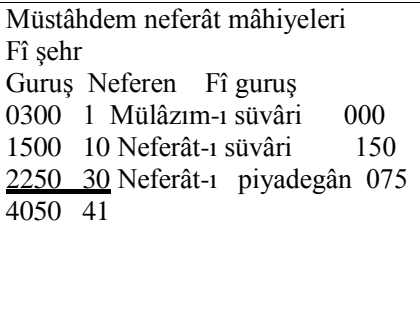 & $\begin{array}{l}\text { Masârıfât-1 müte'arife } \\
\text { Posta tatarlarının râkib oldukları } \\
\text { hayvanât ücretleri } \\
\text { Guruş Re's Sâ'at Fiyât Def'â } \\
192 \quad 3 \quad 8\end{array}$ & $\begin{array}{l}\text { Posta } \\
\text { hayvâvâtı } \\
\text { müdürü } \\
\text { Mehmed } \\
\text { Ağa } \\
\text { mâhiyesi } \\
\text { Fî şehr } \\
\text { Guruş } \\
100\end{array}$ \\
\hline \multicolumn{5}{|c|}{$\begin{array}{c}\text { Yekûn } \\
\text { Guruş5614 }\end{array}$} \\
\hline
\end{tabular}

Nazilli kazası masrafları nüfus müdürüne ödenen 50 guruş ile başlamaktadır.Kazada altı kişiden oluşan ihtisab memurluğunun maaşlarının toplamı 1150 guruş olarak kayıt altına alınmıştır. Kazanın askeri personeli olan 41 kişiye 4050 guruş maaş ödemesi yapılmıştır. Bunların içerisinde 1 teğmen 300 guruş maaş alırken, süvari ve piyade askerlerin maaşları diğer kazalarda olduğu şekliyle kayıtlanmıştır.Kazanın diğer masrafları posta işleri kaynaklı masraflardır. Posta hayvanat müdürüne 100 guruş maaş ödenirken, postatatarlarına ise 264 guruş masraf yapılmıştır. Nazilli kazasının yekün hanesine bütün bu maaş ve diğer masrafların toplamı olarak 5614 guruş muhasebeleştirilmiştir. Belgenin devamında Kuyucak Kazası masrafları bulunmaktadır.

\subsection{Kuyucak Kazası Masrafları}

Tablo 22.Kuyucak Kazası Masrafları

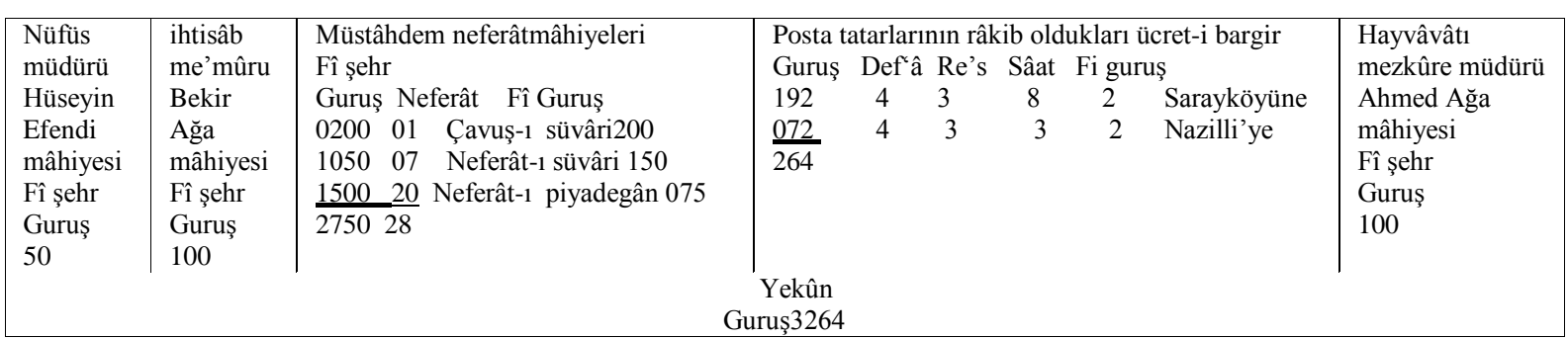


Kuyucak Kazası'nın nüfus müdürünün maaşı, 50 guruş, ihtisab memurunun maaşı 100 guruş ve askeri personele ödenen maaş toplamı 2750 guruştur. Askeri personel sayısı 28 kişiden oluşmakta olup, 1'i süvari çavuşu, 7'si süvari ve 20'si piyade neferidir.Askerlerin maaşları sırasıyla 200, 150 ve 75 guruştur.Diğer kaza masrafları posta müdürünün 100 guruş ve posta tatarlarının 264 guruşluk ödemeleridir.Böylelikle kazanın toplam masrafı 3264 guruş olarak belgede muhasebeleştirilmiştir. Masraf defterinde Kuyucak Kazası'ndan sonra Aydın Yenişehir Kazası'nın masrafları kayıt altına alınmıştır.

\subsection{Karacasu (Aydın Yenişehir) Kazası Masrafları}

Tablo 23. Karacasu (Aydın Yenişehir) Kazası Masrafları

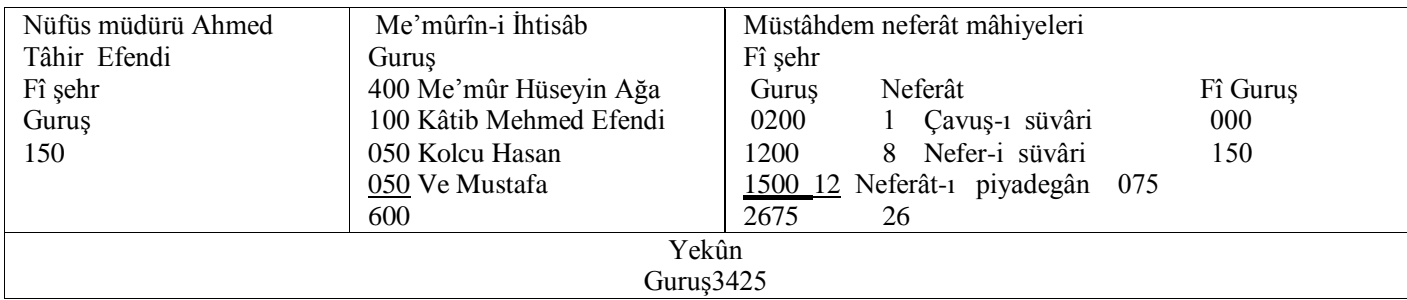

Yenişehir Kazası'nın masraflarının tamamı memur maaşlarından oluşmaktadır. Belgede kayıtlandığı üzere nüfus müdürünün maaşı 150 guruş, 4 kişi olan ihtisab memurlarının maaşları toplamı 600 guruş ve 26 nefer olan askeri personelin maaş toplamı 2675 guruştur. Kazada en yüksek maaşı 400 guruş ile ihtisab memuru alırken en düşük maaş1 ise yine ihtisab memurluğunda görevli 2 memur almıştır.Kazanın bütün memur maaşlarının toplamı 3425 guruş olarak muhasebeleştirilmiştir. Devam eden kısımda Balyanbolu Kazası masraflarının kayıtları bulunmaktadır.

\subsection{Balyanbolu Kazası Masrafları}

Tablo 24.Kazâ-yı Balyanbolu Masrafları

\begin{tabular}{|c|c|c|}
\hline $\begin{array}{l}\text { Nüfüs müdürü İbrâhim Efendi } \\
\text { Fî şehr } \\
\text { Guruş } \\
50\end{array}$ & $\begin{array}{l}\text { Müstâhdem neferât mâhiyeleri } \\
\text { Fî şehr } \\
\begin{array}{llll}\text { Guruş } & \text { Neferen Fî Guruş } \\
200 & 1 & \text { Çavuş-1 süvâri } & 200 \\
300 & 2 & \text { Neferât-1 süvâri } & 150 \\
\frac{1275}{1775} & 17 & \text { Neferât-1 piyadegân } & 075 \\
& & & \\
& & & \text { Yekûn } \\
& & \text { Guruş1900 }\end{array}\end{array}$ & $\begin{array}{l}\text { Masârıfât-1 Müteferrikasi } \\
\text { Guruş } \\
35 \text { Bahâ-yı kâğıd Deste (7) Fî guruş ( 5) } \\
\frac{15}{50} \text { Mürekkeb şişe Aded (1) } \\
\frac{25}{75} \text { Vergi içün defter Aded (2) Fî Guruş (12) }\end{array}$ \\
\hline
\end{tabular}

Balyanbolu Kazası'nda ihtisab memurluğu bulunmamaktadır. Ancak nüfus memuru ve askeri personel bu kazada da maaş alan çalışanlardır. Nüfus müdürünün maaşı 50 guruş, 20 nefer olan askeri personelin maaşi ise toplam 1775 guruştur. Askeri personelden 1 çavuş 200 guruş, 2 süvari neferi 300 guruş, 17 piyade neferi de toplam 1275 guruş maaş almıştır. Kazadaki diğer masraflar, kağıt, mürekkep ve defter bedellerinden oluşmakta ve bunların toplamları 75 guruş olarak kayıtlanmıştır.Kazanın toplam masrafı belgede 1900 guruş olarak muhasebeleştirilmiştir.Belgenin bir sonraki kazası, Bozdoğan Kazası'dır. 


\subsection{Bozdoğan Kazası Masrafları}

Tablo 25.Bozdoğan Kazası Masrafları

\begin{tabular}{|c|c|c|c|}
\hline $\begin{array}{l}\text { Nüfüs müdürü } \\
\text { Hasan Efendi } \\
\text { mâhiyesi } \\
\text { Fî şehr } \\
\text { Guruş } \\
75\end{array}$ & $\begin{array}{l}\text { Me'mûrîn-i ihtisâb } \\
\text { Guruş } \\
125 \text { Me'mûr kâtib Ömer Efendi } \\
\frac{050}{175} \text { Kolcu Ahmed }\end{array}$ & $\begin{array}{l}\text { Müstâhdem neferât } \\
\text { mâhiyeleri } \\
\text { Fî şehr } \\
\text { Guruş Neferen Fî guruş } \\
1500 \quad 10 \text { Süvâri } 150 \\
\frac{1350}{2850} \quad 18 \text { Piyadegân } 075\end{array}$ & $\begin{array}{l}\text { Masârıfât-1 Müteferrikasi } \\
\text { Guruş } \\
72 \text { Aydın'a irsal olunan akçenin bargir ücreti Re's } \\
\text { (3) Sa'ât } 12 \text { Fiyat (2) } \\
16 \text { Bahâ-yı torba Aded (4) Fî guruş } 4 \\
20 \text { Mahbûshâne içün revgân-1 zeytin Kıyye (5) Fi (4) } \\
\frac{16}{12} \text { Bî kes mahbûsâna verilen nân bahâsı }\end{array}$ \\
\hline \multicolumn{4}{|c|}{$\begin{array}{c}\text { Yekûn } \\
\text { Guruş3224 }\end{array}$} \\
\hline
\end{tabular}

Bozdoğan Kazası'nın masraflarının kaydı, 75 guruş maaş alan nüfus müdürü ile başlamaktadır. Devam eden kayıtlarda ihtisab memurluğunda görevli iki memurun 175 guruşluk maaşları yer almaktadır. Belgenin kaza ile ilgili üçüncü kısmında, 28 nefer olan 2850 guruşluk askeri personelin maaşı kayıt altına alınmıştır.Kazanın çeşitli masraflarının toplamı ise, 124 guruş olarak gösterilmiştir.Kazanın masraflarının toplamı 3224 guruş olarak muhasebeleştirilmiştir. Devam eden kısımda Kıran Nahiyesi'nin maaşları bulunmaktadır.

\subsection{Kuran Nahiyesi Masrafları}

Tablo26.Kıran Nahiyesi Maaşları

\begin{tabular}{|lcc}
\hline \multicolumn{3}{|l}{ Müstâhdem neferâtı mâhiyeleri } \\
Fî şehr & & \\
Guruş & Neferât & Fî Guruş \\
150 & $1 \quad$ Süvâri & minû \\
$\frac{1502}{300}$ & $\begin{array}{c}\text { Piyadegân } 75 \\
3\end{array}$ & \\
& 3 &
\end{tabular}

Kıran Nahiyesi'nin masrafi olarak sadece üç nefer olan askeri personelin maaşı kayıtlanmıştır.Bu askerlerden biri süvari, maaşı 150 guruş, ikisi piyade olup maaşları 75'er guruştan toplam 150 guruştur.Nahiyenin toplam masrafi da 300 guruş olarak muhasebeleştirilmiştir. Kıran Nahiye'si Aydın Sancağı içerisindeki yerleşim birimlerinden en az masraflı olan nahiyedir. Belgenin bir sonraki kazası Arpaz Kazası'dır.

\subsection{Arpaz Kazası Masrafları}

Tablo 27.Arpaz Kazası Masrafları

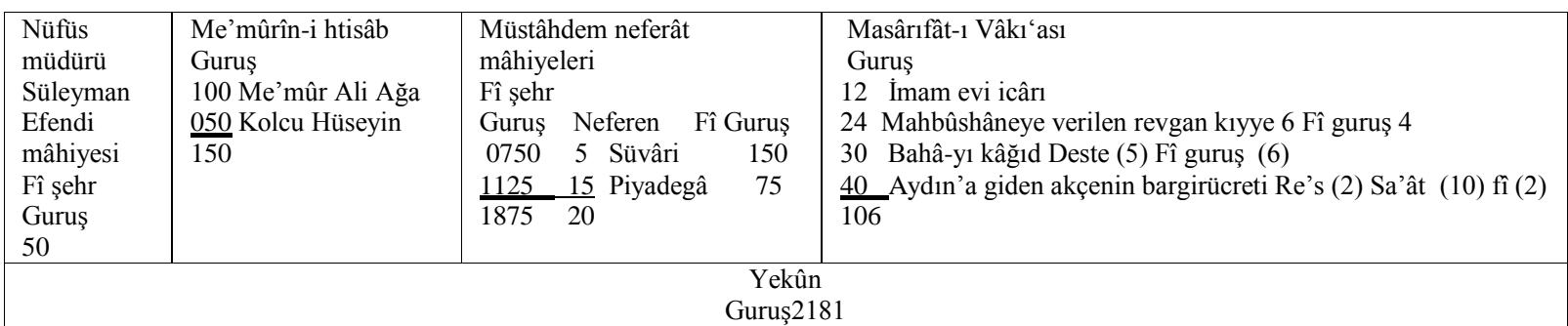

Arpaz Kazası muhasebe kayıtları, memur maaşları ve çeşitli masraflardan oluşmaktadır. Memur maaşları, nüfus memurunun 50 guruş, ihtisab memuru olan iki kişinin 150 guruş maaşlarından ve 20 nefer askeri personelin toplam 1875 guruş olan maaşından oluşmaktadır. Çeşitli masraflar, imam evi kirası, mahbushane revganı, kağıd bedeli ve beygir ücretinden oluşmakta olup toplam 106 akçedir. Kazanın hem memur maaşları hem de çeşitli giderlerinin toplamı 2181 guruş olarak muhasebeleştirilmiştir. Devam eden kısımda Aydın Yenipazarı Kazası kayıtlanmıştır. 


\subsection{Aydın Yenipazarı Kazası Masrafları}

Tablo 28.Aydın Yenipazar-ı Kazası Masrafları

\begin{tabular}{|c|c|c|c|}
\hline $\begin{array}{l}\text { Nüfüs müdürü } \\
\text { Ahmed Hûrşid } \\
\text { Efendi } \\
\text { mâhiyesi } \\
\text { Fî şehr } \\
\text { Guruş } \\
20\end{array}$ & $\begin{array}{l}\text { Me'mûrîn-i İhtisâb } \\
\text { Fî şehr } \\
\text { Guruş } \\
150 \text { Me'mûr Sâlih } \\
\text { Ağa } \\
\text { 050 Kolcu } \\
\text { Süleymân } \\
200\end{array}$ & $\begin{array}{l}\text { Müstâhdem neferâtı mâhiyeleri } \\
\text { Fî şehr } \\
\begin{array}{llc}\text { Guruş Neferen } & \text { Fî Guruş } \\
0750 \quad 05 \quad \text { Süvâri } & 150 \\
\frac{0900 \quad 12}{1650 \quad 17} \text { piyâdegân } & 075\end{array}\end{array}$ & $\begin{array}{l}\text { Masârıfât-1 Müteferrikasi } \\
\text { Guruş } \\
160 \text { Sekiz bâb â‘şâr anbârlarının kiremid akdarması } \\
\text { Nefer (5) Fî guruş (8) Eyyam (4) } \\
075 \text { Kiremid altına tahta aded (200) fiyat (15) } \\
025 \text { Mismar Kiyye (5) (05) } \\
050 \text { Zahire anbârların kilid bahâ aded (10) fî guruş (5) } \\
160 \text { Â‘şâr istahsâli içün mübâyaa olunan ayâr çift (8) } \\
\text { Fî guruş (20) } \\
\text { 031.50 Ayâr-1 mezkûrenin demir-i kende masârıfâtı } \\
030 \text { Bahâ-yı kâğıd deste (5) fî guruş (6) } \\
\text { 020 Mahbûshâneye mübayaa olunan revgan-1 zeytin } \\
\text { Kiyye (4) Fiyat (5) } \\
551.50\end{array}$ \\
\hline \multicolumn{4}{|c|}{ Yekûn } \\
\hline
\end{tabular}

Aydın Yenipazarı Kazası'nın kayıtları nüfus memurunun 20 guruş olan maaşı ile başlamaktadır. Devam eden kısımda, toplam 200 guruş olan iki ihtisab memurunun maaş1 ve 17 neferin toplam 1650 guruş olan maaşı kayıtlanmıştır. Kazaya ait son kayıt "masarifat1 müteferrikası" başlığı ile kaydedilen 551.50 guruşluk harcamalardır.Kazanın toplam masrafları 241.50 guruş olarak muhasebeleştirilmiştir. Defterin devam eden kısmında Amasya Kazası'nın masraf kayıtları bulunmaktadır

\subsection{Amasya Kazası Masrafları}

Tablo 29.Amasya Kazası Masrafları

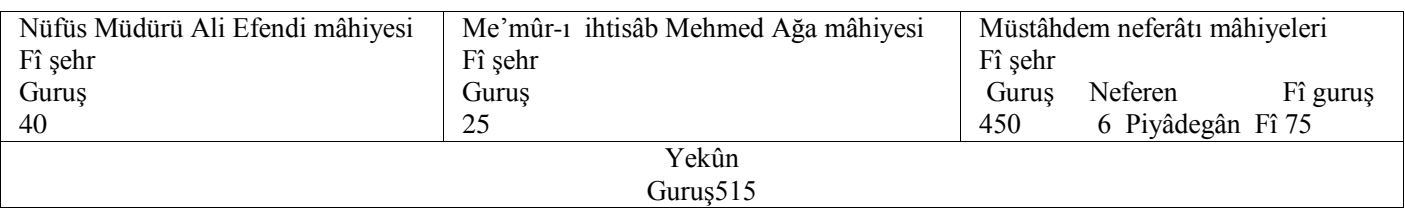

Amasya Kazası'nın masraflarının tamamı memur maaşlarından oluşmaktadır. Sekiz kişi olan toplam kaza memurunun biri nüfüs müdürü, diğeri ihtisab memuru ve kalanları da askeri personeldir. Bahsedilen memurların maaşları sırasıyla 40, 25 ve altı askerin toplam maaşı 450 guruştur.Kazanın toplam masrafı belgede 515 guruş olarak muhasebeleştirilmiştir.Bir sonraki kayıtlı kaza, Çine Kazası'dır.

\subsection{0. Çine Kazası Masrafları}

Tablo 30.Çine Kazası Masrafları

\begin{tabular}{|c|c|c|c|}
\hline $\begin{array}{l}\text { Nüfüs müdürü Yusuf } \\
\text { Efendi mâhiyesi } \\
\text { Fî şehr } \\
\text { Guruş } \\
60\end{array}$ & $\begin{array}{l}\text { Me'mûrîn-i ihtisâb } \\
\text { Hasan Ağa mâhiyesi } \\
\text { Fî şehr } \\
\text { Guruş } \\
200\end{array}$ & 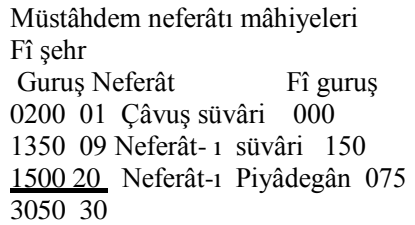 & $\begin{array}{l}\text { Posta sürücüsü Mehmed } \\
\text { ve Ahmed'in Mâhiyesi } \\
\text { Fî şehr } \\
\text { Guruş } \\
50 \text { Mehmed } \\
\text { 50 Ahmed } \\
100\end{array}$ \\
\hline \multicolumn{4}{|c|}{$\begin{array}{c}\text { Yekûn } \\
\text { Guruş3410 }\end{array}$} \\
\hline
\end{tabular}

Çine Kazası'nın toplam masrafı 3410 guruş olarak muhasebeleştirilmiştir. Bunun 60 guruşu nüfus müdürünün, 200 guruşu ihtisab memurunun, 3045 guruşu 30 nefer askeri personelin ve 100 guruşu da posta sürücüsü olan iki memurun maaşıdır. Kazada askeri personel olarak 1 süvari çavuşu 200 guruş maaşla, 9 süvari neferi 150 'şer guruş maaşla ve 20 piyade neferi ise 75 'er guruş maaşla görev yapmıştır. Devam eden kısımda Karpuzlu Kazası'nın masrafları kayıtlanmıştır. 


\subsection{Karpuzlu Kazası Masrafları}

Tablo 31.Karpuzlu Kazası Masrafları

\begin{tabular}{|l|l|lc|}
\hline Nüfüs Müdürü Mustafa & Me'mûrîn-i İhtisâb mâhiyesi & Müstâhdem neferâtı mâhiyeleri & \\
Efendi mâhiyesi & Fî şehr & Gưhr & Fî guruş Neferen \\
Fî şehr & Guruş & $0200 \quad 01$ Çavuş-1 süvari & minhû \\
Guruş & 100 Me'mûr Hasan Ağa & $0600 \quad 04$ Neferât-1 süvâri & 150 \\
50 & $\frac{080 \text { Kâtib İbrâhim Ağa }}{180}$ & $\frac{090012}{1700 \quad 17}$ Neferât-1 Piyadegân & 075 \\
& \multicolumn{3}{|c|}{ Yekûn } \\
\hline \multicolumn{2}{|c|}{ Guruş1930 } \\
\hline
\end{tabular}

Karpuzlu Kazası'nın masrafları sadece memur maaşlarından oluşmaktadır. Belgeye göre kazada maaş alanlar, nüfus müdürü, iki kişi olan ihtisab memurluğu çalışanları ve 17 askeri personeldir. Kazadaki memurların maaşları sırası ile 50 guruş, 180 guruş ve 1700 guruştur.Askeri personel bir çavuş, dört süvari neferi ve 12 piyade neferinden oluşmaktadır.Bu memurların maaşları da diğer kazalardakilerle aynıdır.Masraf defterinde masrafları kayıtlanan son kaza Şahme Kazası'dır.

\subsection{Sahme Kazası Masrafları}

\section{Tablo 32.ŞahmeKazası Masrafları}

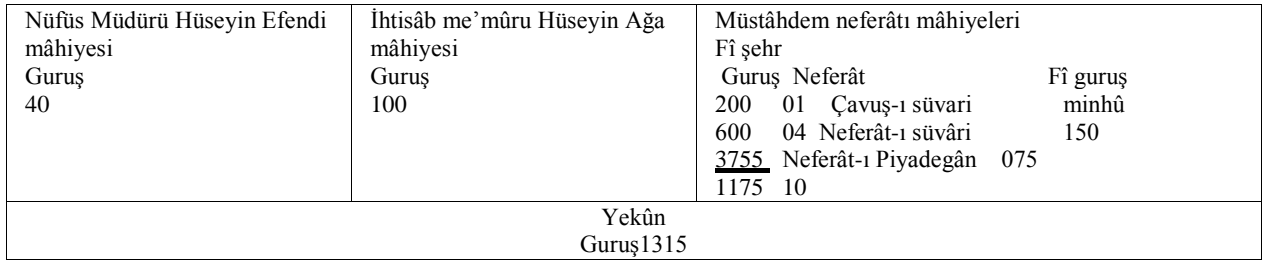

Şahme Kazası masrafları da Karpuzlu Kazası masrafları gibi sadece memur maaşlarından oluşmaktadır.Kazada nüfus memuru 40 guruş, ihtisab memuru 100 guruş ve 10 nefer olan askeri personel ise toplam 1175 guruş maaş almışlardır. Askeri personelin biri süvari çavuşu, dördü süvari neferi ve beşi piyade neferi olarak kaydedilmiştir.

Belgenin sonunda "Meblâğ-ı mezbûr Aydın Sancă̆ı'nın elli dokuz senesi vergisine mahsûb buyurulacak olmağla şerh-ı hesâb ola" düşülerek sancağın bütün kazalarının masrafı 201472 guruş olarak yekünlenmiştir. Ayrıca muhasebe kayıtlarına ilişkin şu şekilde bir kapanış notu düşülmüştür;

Aydın Sancağı dâhilinde vâkl' muharrerü'l-ism kazâların elli dokuz senesi haziran mâhına mahsûben bi'l-cümle me'mûrîn ma 'âş ve mâhiye ile masârlfât-l sâ 'ireye ber vech-i balâ iki yüz bin dört yüz yetmiş iki guruşa baliğ olmağla makâm-ı aliyyeleri buyuruldukda ol bâbda emr-i fermân hazret-ii me'n-leh'ül emrindir.

Muhasebe defterinin sonunda kayıtları onaylayan kişilerin isimleri ve görevleri mühürlerden ortaya çıkmaktadır. Mühürlerin transkripsiyonu şu şekildedir;

$$
\begin{gathered}
\text { bende }{ }^{39} \text { aza Abdihi (kulunuz) Ahmed } 1230 \\
\text { Bende Aza Mustafa Hasib } \\
\text { Bende Aza (Mühür okunmuyor) } \\
\text { Esseyyid ed-dai Kadt? (Mühür okunmuyor) } \\
\text { es-Seyyid ed-dai Hakim Hasbi } \\
\text { Bende Defterdar es-Seyyid.... Muhammed } \\
\text { Bende Abdihi Yakub } \\
\text { Bende Aza Mehmed Emin } \\
\text { Bende Aza Mehmed Hüdaverdi }
\end{gathered}
$$

Toplam dokuz mühür bulunan belgeyi azalar, kadı, defterdar gibi görevlerdeki kişiler onaylamıştır.

\footnotetext{
${ }^{39}$ Bende: Hizmetkar, kul.
} 


\section{Sonuç}

Aydın Sancağı'nın 4'ü nahiye (Kıran, Çakıllı, Koçak, Karapınar), 28'i kaza (Aydın Güzelhisarı, Köşkderesi, Köşk, İnce, Sultanönü, Dallıca, Sobuca, Mazun, Dalama, Ayasuluğ, Tire, Bayındır, Birgi, Ödemiş, Keles, Alaşehir, İnegöl, Nazilli, Kuyucak, Karacasu, Balyanbolu, Bozdoğan, Arpaz, Yenipazar, Amasya, Çine, Karpuzlu, Şahme) olmak üzere 1843 M. yılının Haziran/Temmuz(1259 R.) aylarının masraf (gider) defteri çözümlendiğinde yerleşim birimlerinin muhasebe kayıtlarının, oldukça düzenli ve sistemli olarak tutulduğu tespit edilmiştir. Muhasebe defterinden yerleşim yerlerindeki devlet memurlarının kimlerden oluştuğunu, devlet adına iş yapan bu kişilerin ne kadar maaş aldıkları, devlet temsilcisi olarak yerlerşim yerinde işlerin yapılmasındaki çeşitli harcamaların neler olduğu hakkında bilgiye ulaşılmıştır. Deftere göre;

- Sancak giderlerinin toplamı 201.472 guruştur. En yüksek gidere sahip yerleşim birimi Aydın Güzelhisarı Kazası'dır. Kazanın toplam masrafı 114.534 guruștur. Bu gider toplam giderin \%56,85'sidir. İkinci en yüksek giderli kaza, Tire Kazası'dır. Tire Kazası'nın toplam gideri 10.272,50 guruş olup, sancak giderlerinin toplam giderleri içerisindeki pay1 \%5,10'dir. Diğer yerleşim yerlerinin masraflarını hem tutar hem de genel sancak içersindeki payları açısından en fazla olandan itibaren sıralanırsa; Bayındır (\%4,40) 8.874 guruş, Alaşehir (\%3,30), 6640,50 guruş, Ödemiş $(\% 3,11) 6265$ guruş, Nazilli $(\% 2,79) 5614$ guruş, Birgi (\%2,78), 5594, Sobuca (\%1,83) 3690 guruş, Karacasu $(\% 1,79)$ 3425, Çine $(\% 1,69)$, 3410 guruş, Kuyucak $(\% 1,62) 3264$ guruş, Bozdoğan $(\% 1,60), 3224$ guruş, İnegöl $(\% 1,21)$, 2447,50, Yenipazar $(\% 1,20) 2421,5$ guruş, Arpaz $(\% 1,08) 2181$ guruş, Karpuzlu $(0,96)$ 1930, Balyanbolu $(\% 0,94) 1900$, Keles $(\% 0,94) 1895$, Sultanönü $(\% 0,91) 1840$, İnce $(\% 0,75) 1515$ guruş, Dalama $(\% 0,72) 1455$, Köşkderesi $(\% 0,67), 1350$ guruş, Ayasuluğ $(\% 0,67), 1350$ guruş, Şahme (\%0,65) 1315 guruş, Dallıca (\%0,52), Karapınar (\%0,45), Köşk $(\% 0,37)$, Koçak $(\% 0,29), 575$ guruş, Mazun $(\% 0,26) 525$ guruş, Amasya $(\% 0,26) 515$ guruş, Çakıllı (\%0,22), Kıran (\%0,15), 300 guruştur.

- Yerleşim yerlerinin giderlerinin öne çıkanları, müşirin maaşı, defterdarın maaşı, ketebe memurlarının maaşı, nüfus nazırının maaşı, nüfus müdürlüğü çalışanlarının maaşı, ihtisab memurluğunun çalışan maaşları, askeri personelin maaşları, karantina memuru maaşları, sandık emini, posta müdürü, mahbushane giderleri ve kazaların çeşitli giderleri olarak sıralanmaktadır. Ancak müşir, defterdar, ketebe memurları, nüfus nazırı sadece Aydın merkez kazası olan Güzelhisar'da görev yapmaktadırlar. Diğer giderler ihtiyaç duyulan yerleşim yerlerinin önemli kısmında bulunmaktadır. Güzelhisar'daki kayıtlanan gider kalemleri, maraşelin maaşı, 67.500 guruş, defterdarın maaşı 11.250 guruş, ketebe memurlarının toplam maaşı 7.950 guruş, nüfus nazının maaşı 500 guruş, nüfus müdürlüğü memurlarının maaşı 250 guruş, ihtisab memurluğu çalışanlarının maaşı 2.350 guruş, karantina memurluğunun maaşı 2151 guruş, sandık emininin maaşı 500 guruş, posta müdürünün maaşı 250 guruş, çeşitli giderler 3582,50 guruş olarak kayıtlanmıştır. En az gidere sahip yerleşim yeri olan Kıran'ın giderlerinin tamamı askeri personel maaşlarına aittir.

- Aydın Sancağı'nın giderleri içerisinde en yüksek tutarlı olanı askeri personel maaşlarıdır. Bütün yerlerşim birimlerinde diğer personellerden görev yapan yada maaş alan bulunmasa bile her kaza yada nahiyede mutlaka askeri personel görev yapmıştır. Bütün sancak yerlerşim birimlerindeki askeri personelin toplam gideri 88.070 guruş olup, bu tutarın toplam giderler içindeki payı \%43,71'dir. Sancak içerisindeki en yüksek ikinci gider, Güzelhisar kazasında yerleşik olan Müşir Paşa'ya aittir. 67.500 guruş olan maaşın genel giderler içindeki payı, \%33,50'dir. Aydın Sancağı'nın en yüksek üçüncü gider kalemi, 
ihtisab memurluğu çalışanlarına ödenen 12.590 guruş olan maaşlardır. Bu maaşların toplam içindeki payı, \%6,25'dir. Diğer masraf kalemleri yüksekten düşüğe doğru sıralanırsa, $\% 5,58^{\prime}$ 'lik payla 11.250 guruş olan defterdar maaş1, $\% 3,95^{\prime}$ 'lik payla 7.950 guruş olan ketebe memurlarının maaşları, \%3,64'lik payla 7.337,50 guruş olan çeşitli giderler, \%1,28'lik payla 2.571 guruş olan karantina memurlarının maaşları, \%1,25'lik payla 2.195 guruş olan nüfus müdürlüğü çalışanlarının maaşlarıdır.Posta müdürlüğü çalışanlarının 850 guruş ve nüfus nazırının ile sandık emininin 500'er guruş olan maaşları, mahbushanenin 153 guruş olan giderlerinin genel giderler içindeki payı ise, \%0,99'dur.

- Muhasebe defteri çözümlendiğinde sancak içerisindeki devlet görevlilerinin (hizmetlilerinin) sayısı bilgisine de ulaşılmıştır. Belgeye göre görevliler, 1'er kişi müşir, defterdar, nüfus nazırı ve sandık emini, 5 posta müdürü, 7 muhasebe çalışanı, 10 karantina memurluğu çalışanı, 22 nüfus müdürlüğü çalışanı, 90 ihtisab memurluğu çalışanı, 266'sı süvari, 611'i piyade olmak üzere 877 askeri personelden oluşmaktadır. Deftere göre Aydın Sancağı'nın 1259 R. (1843 M.)senesi haziran ayındaki çalışanlarının sayısı, 1015'tir.

Defterde dönemin hesaplama araçları ve imkânları değerlendirildiğinde hiç önemi olmayan ancak muhasebe açısından önemli olan 0,50 guruşluk Güzelhisar Kazası kayıtları gerçekleştirilirken toplama hatası yapıldığı tespit edilmiştir.

Masraf defteri muhasebe kavram ve ilkeleri açısından incelendiğinde, dönemlere ayrılması ile dönemsellik, her kaydın açıklamalarının olması yönünden tam açıklama, kayıtların para birimleri ile tutulması yönü ile parayla ifade edilebilme, özellikle malzeme satın alma yani maliyetlerin kayıtlanması yönü ile, maliyet esası ve bazı kayıtlarda en ince ayrıntının dahi unutulmadan gösterilmesi önemlilik kavramları ile yakından ilişkilidir.

Gelecek çalışmalarda Aydın Sancağı ile diğer sancakların aynı zaman dilimindeki masraflarıçözümlenebileceği gibi, aynı sancağın farklı ay ya da yıllardaki masraf defterleri çözümlenerek karşılaştırmalı analizler yapılabilir. Ayrıca bütçe açıklarının arttığı dönemlere rastlayan belge tarihinden yola çıkılarak, aynı ayın gelirlerinin çözümlenmesi sonrasında bütçe denklikleri yada eşitsizlikleri gelecekteki çalışmalara konu edinilebilinir.

\section{Kaynakça}

Başbakanlık Osmanlı Arşivleri, (BOA), Gömlek No: 4863, Fon Kodu: ML.MSF.d.

Erdoğdu, İbrahim, (2000), “Osmanlı İktisadi Düzeninde İhtisab Müessesesi ve Muhtesiblik Üzerine Bir Deneme”, Ankara Üniversitesi Osmanlı Tarihi Araştırma Merkezi Dergisi, S.11, ss.123-145.

Devellioğlu, Ferit (2008), Osmanlıca-Türkçe Ansiklopedik Lügat, Aydın Kitabevi.

Güneş, Mehmet (2014), “Osmanlı Dönemi Nüfus Sayımları ve Bu Sayımları İçeren Kayıtların Tahlili”, Gazi Akademik Bakış, 8(15), ss.221-240.

Sarıyıldız, Gülden, (2001), Karantina, Türkiye Diyanet Ansiklopedisi, Cilt: 24, Erişim, 12.01.2016, http://www.islamansiklopedisi.info/dia/ayrmetin.php?idno=240464

Uyanıker, Ahmet (2014), Sultan II. Abdülhamid Döneminde Osmanlı Devleti'nde Să̆llk Alanında Yapılan Çalışmalar (1876-1909), Yayımlanmamış Doktora Tezi, Kahramanmaraş, Kahramanmaraş Sütçü İmam Üniversitesi, Sosyal Bilimler Enstitüsü. 